PROFESSIONSHØJSKOLEN

\title{
MEROPnL
}

Udsyn og perspektiv

- om erhvervsuddannelsernes

internationale innovationslegat 


\section{Udsyn og perspektiv - om \\ erhvervsuddannelsernes internationale \\ innovationslegat}

Forfattere:

Pernille Bystrup Holm og Lisbeth Magnussen (red.)

1. udgave, 1. oplag, 2015

ISBN 978-87-7548-145-3

ISBN (www) 978-87-7548-146-0

Elektronisk udgave:

www.phmetropol.dk/publikationer

Udgivet af:

Nationalt Center for Erhvervspædagogik

Professionshøjskolen Metropol

Tagensvej 18

2200 København $N$

Denne publikation udgives også på tysk Weitblick und Perspektive - über den Internationalen Innovationsfonds der Berufsausbildungen

ISBN 978-87-7548-147-7

ISBN (www) 978-87-7548-143-9

Elektronisk udgave:

www.phmetropol.dk/publikationer

Layout og tryk: Bording A/S

Information om EIIL og oversigt over de projekter, der har modtaget støtte, findes på www.phmetropol.dk/publikationer

Stor tak til Karen Elisabeth Lundbæk, som har oversat til tysk og til Werner Hedegaard, som har korrekturlæst. 


\section{Indhold}

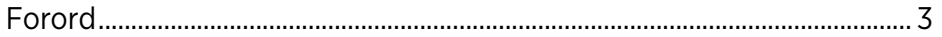

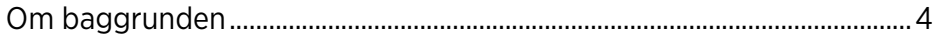

Frem mod målet - konkurrencer og mesterskaber .................................... 6

Innovation og entreprenørskab i undervisningen ................................... 10

God praktikoplæring i erhvervsuddannelserne .....................................13

Mentorordning under udvikling....................................................................17

Cooperative Learning - en del af hele skolens tankesæt ........................19

Den globale praktikplads................................................................................22

Læringsprocesser i håndværk .................................................................26

Kreativitet, innovation og iværksætterkultur ............................................. 30

Udenlandske erhvervsuddannelser under lup ............................................33 

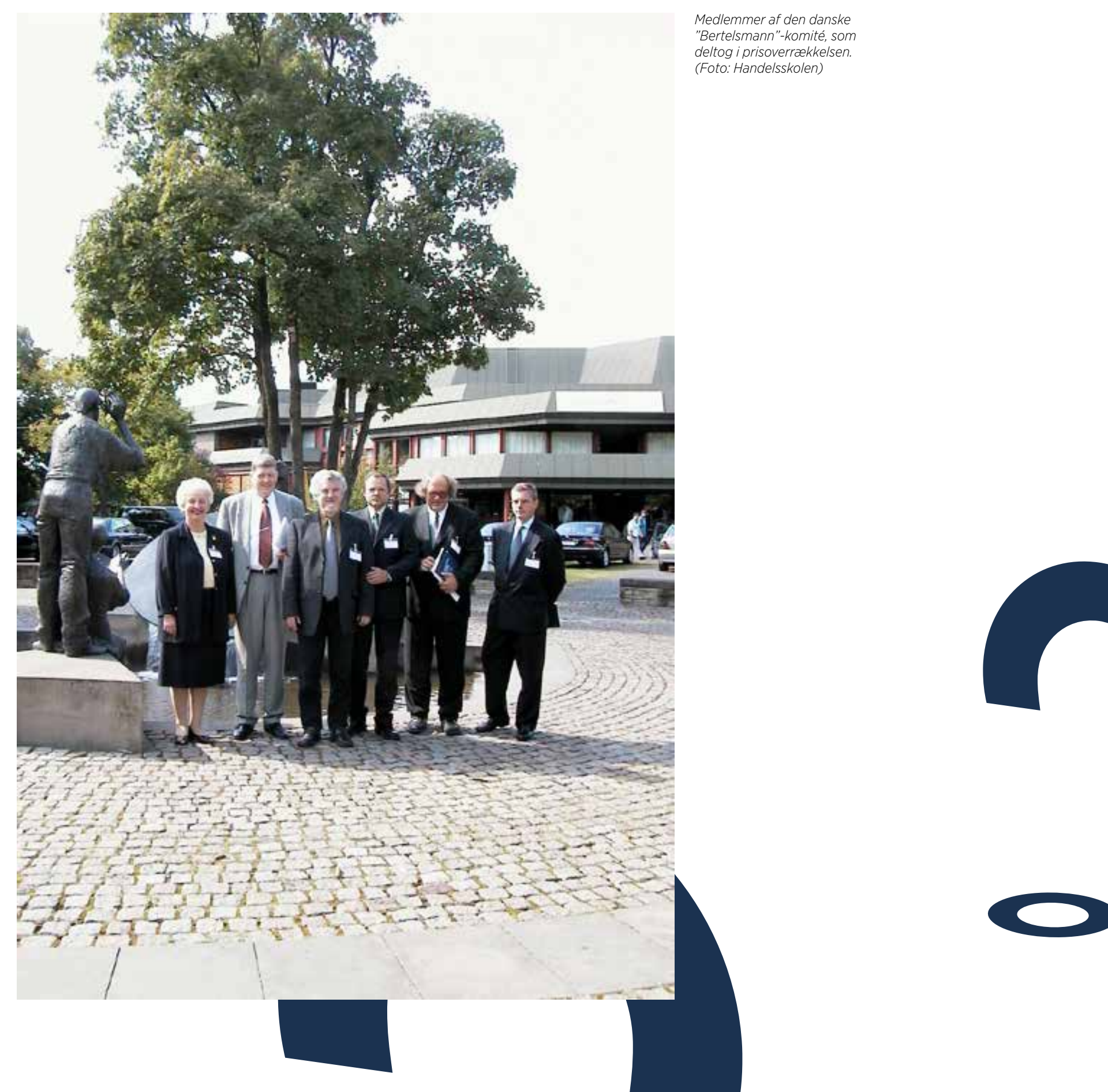


\section{Forord}

Erhvervsuddannelsernes internationale Innovationslegat (EIIL) blev stiftet, efter at Danmark i 1999 fik den tyske Bertelsmann-pris for at have verdens bedste erhvervsuddannelser. Legatet skulle give aktører i det danske erhvervsuddannelsessystem mulighed for at hente inspiration og viden hjem fra udlandet.

EIIL har i perioden 2001-2011 støttet mere end 90 projekter, hvor engagerede aktører inden for det erhvervspædagogiske felt har rejst forskellige steder hen i verden. Rejserne er bl.a. gået til Australien, USA og mange europæiske lande. I nogle tilfælde er også udenlandsk ekspertise hentet til Danmark.

EIIL-bestyrelsen har derfor besluttet at udgive denne publikation, som præsenterer eksempler på nogle af de aktiviteter, som har modtaget legatmidler. Beskrivelserne er blevet til på baggrund af interview med legatmodtagere, og der er tilstræbt en sådan dækning, at alle typer aktører, vidt forskellige rejsemål og en bred vifte af faglige temaer er repræsenteret.

Publikationen udgives i både elektronisk og trykt form og den udgives tillige på tysk, således at vi over for Bertelsmann-fonden kan dokumentere prisens anvendelse.

Bestyrelsen vil gerne takke alle publikationens bidragydere, redaktørerne og sekretariatet, som i alle årene har været forankret i Nationalt Center for Erhvervspædagogik.

På EllL-bestyrelsens vegne

Inge Mærkedahl

formand 


\section{Om \\ baggrunden}

Den 16. september 1999 modtog daværende undervisningsminister Margrethe Vestager den prestigefyldte Carl Bertelsmann Pris på 300.000 DM i Gütersloh i Tyskland. Prisen, som også kaldes for "Tysklands svar på Nobelprisen", uddeles hvert år inden for et i forvejen udvalgt emne. I 1999 var emnet faslagt til at være "Morgendagens erhvervsuddannelser", og et ekspertpanel vurderede erhvervsuddannelsessystemer over hele kloden for at finde "exemplary social innovations". Det mundede ud $\mathrm{i}$ en nominering af fem lande/regioner, som derefter blev meget grundigt analyseret af et internationalt konsulentfirma ud fra et sæt kriterier, formuleret af Bertelsmann Foundation. Kriterierne var samlet under fire overskrifter: Samspillet mellem aktørerne i systemet, Udviklingen af kvalifikationer og kompetencer, Systemets struktur og organisation samt Kvalitetsudvikling og finansiering. Hele denne omfattende proces resulterede $i$, at de danske erhvervsuddannelser blev udpeget som en model for resten af verden.

Ministeren sagde allerede i sin takketale, at prisen på ca. 1,2 mio. kr. skulle bruges til et innovationslegat ("Erhvervsskolernes Internationale Innovationslegat, EIIL"), der skulle uddeles i samme ånd, som Bertelsmannprisen var modtaget: Pengene skulle bidrage til, at Danmark fortsat hentede og modtog inspiration fra resten af verden. Ministeren supplerede med et tilsvarende beløb fra tipsmidlerne, og legatet kom således til at råde over ca. 2,7 mio. kr. I 2002 besluttede Teknisk Skoleforening at nedlægge en ældre rejsefond og donerede restbeløbet i fonden til EIIL. Sammen med de oprindelige midler og ministerens særbevilling gav dette et samlet rådighedsbeløb på godt 3 mio. kr.

Formålet med legatet blev at give erhvervsuddannelsessystemets aktører mulighed for at hente inspiration og viden hjem fra udlandet, hvis det vurderes at kunne bidrage til at løfte erhvervsuddannelserne i Danmark. Det blev Danmarks Erhvervspædagogiske Læreruddannelse (DEL), der fik opgaven med at forvalte legatet i samarbejde med en legatbestyrelse. Bestyrelsens formand er formanden for Rådet for de grundlæggende Erhvervsfaglige Uddannelser (REU), og medlemmerne repræsenterer Undervisningsministeriet samt de tekniske skoler og handelsskolerne. Endvidere er lederen af DEL (nu NCE - Nationalt Center for Erhvervsuddannelse) med $\mathrm{i}$ arbejdet sammen med sekretariatet.

Legatet har støttet aktiviteter, hvis sigte har været at lære af udenlandske erfaringer på erhvervsuddannelsesområdet. Det er sket i forhold til bl.a. studierejser til udlandet knyttet til konkret forsøgs- og udviklingsarbejde i Danmark, deltagelse i internationale konferencer, seminarer og erfaringsudvekslingsfora samt spredning af viden om "best practice" i udlandet.

Pengene er nu sluppet op, og det er både med vemod og tilfredshed, at vi nu gør status over indsatsen.

Vi har i dette lille skrift forsøgt at belyse betydningen af "10 år med Bertelsmann" ved at udvælge og beskrive konkrete eksempler på aktiviteter, som har modtaget støtte fra EIIL. 


\section{Danmark er bare bedst Stor pris til de danske erhvervsuddannelser}

gir i den tyake by Gatersloh

Tyskere vil lere af os
De danske erhvervsuddannelser er kåret som verdens bedste af den tyske

Bertelsmann-fond. Undervisningsminister Margrethe Vestager modtog prisen på 1,2 mio. kr., der skal bruges til innovationsfond.

\section{$\overline{\text { Af Henrik Kaufholz. Cutersloh }}$}

De danske erhvervsuddan
nelser er verdens bedste.

Hvis nogle danske larlin.
ge eller handelsskolelerere

er i tvivl, akulle de have hor

og set begejstringen hos 700
tyske erhvervsfolk og politi-

kere, da undervisningsmin.
ster Margrethe Vestager

1999.

Bertelsmann-fonden, der

hvert Ar har knap 400 mio

\section{Storbritannien og Rijnmond/
Rotterdam i Holland. Lige} inden Margrethe Vestager ik overrakt de 1,2 mio. $\mathrm{kr}$. ersloh, der helt domineres af den store mediekoncern,

ike system.
Der blev klappet som efter Dellykket teaterpremien Pă fejlfrit tysk Rundt om pa brenkene var nerede over, at de unge dan.

\section{on innovationsfond for er-} er, at -ministeriet er redo til it skyde yderligere penge Bertelsmann-fonden har pris, der belonner -innovative og eksemplariske losnin. ger pa centrale samfundspe hedder i fundatsen. for at se, hvor man har piort noget, vi og andre kan leere
af-, sugde fondens formand, af-, sngde fondens formand
Mark Wossner. Det er netop, hvad Dan mark har giort, svarede Mar grethe Vestager. Europar lest af resten af er passer tit denete for. til de lokale skolebestyreleer Ogsí den lige adgang og okonomiske stotte under uddan.
nelaen blev fremhervet. nelsen helt utrolig fleksibili. et i sammenligning med Wossne Bertelsmann-koncernen har ner i vinter overlod posten Middelhorf, var det en begivenhed, der blev oververe af ikke blot erhvervalivet top, men ogsas fere tidligere og nuvarende ministre.
Mark Wiksner sagde i gels, Mark Whssner sagde i gair.
at han indtil for to $\mathrm{Ar}$ siden var stolt af den tyske er. hvervsuddannelse, der som ske damfig indinydelse i det ty. set op. Overrwakkelsen led $\mathrm{i}$ vores arbejde. Nu má kan forsoge at fa fort nogle prakais*:
Margrethe Vestager h inden prisoverrokkelsen fo
talt den tyake preses, at talt den tyske presse, at d i mellemtiden er blever yder ligere forbedret 2001 at sikre, at uddann serne ikke blot er tilpass ogsi attraktive for de unge ninger og drommeDanmark. Hiad kan oi Det, viskal hente, er for BLICK IN

\section{Carl-Bertelsmann-Preis 1999}

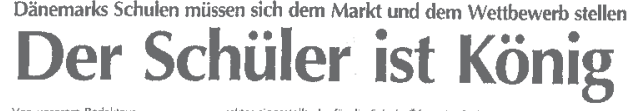
til de unges evner, forven

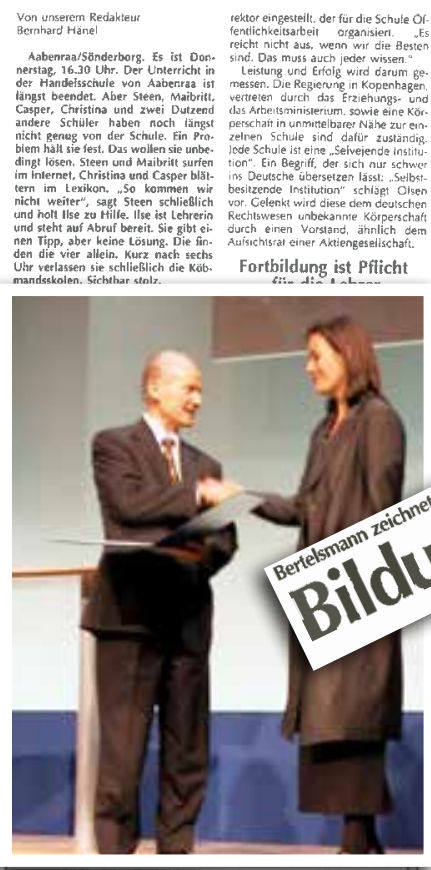

De danske erhvervsuddannelser

Carl Bertelsmann Prisen er siden 1988 blevet uddelt af Bertelsmann Stiftung til innovative og eksemplariske lasninger pá centrale sociale og politiske problemer. Prisen er pá 300,000 DM, hvilket svarer til ca.

1,2 rnillioner $\mathrm{kr}$.

Danmark vandt prisen i tæet konkurrence med Holland. Frankrig, Storbritannien og USA, som ogsá var udtaget uddannelser, eller. som det hedder prisuddelingen. „Das Königreich Dănemark", fảr Carl Bertelsmann Prisen for at være et eksempel ti] efterfølgelse for andre lande. I ăr gives prisen for nye màder at lose problemer pá i erhvervsuddannelserne, og prisuddeleme lægger i begrundelser uddannelsers evne til fornyelse.

En stolt minister

Undervisningsministeren var med ved prisoverræekkelsen i Gütersloh

- Jeg er stolt og glad, fordi jeg som den overste ansvarlige for de danske uddannelser modtager prisen for nye og innovative mäder at tilrettelægge erhvervsuddannelserne pá. Og jeg er ydmyg. fordi jeg ved, hvor mange forskellige aktører, der har været med iil konkurencen. De danske erhvervs særlifg vægt pá de danske erhvervstil at skabe denrie succes, og jeg ved
Den pris, vi modtager i dag, har international orientering og er funderet pá det sym, at man ofte kan finde nye losningsmodeller pả socia akonomiske og politiske problemer .by looking beyond the garden fence. som det hedder $\mathrm{i}$ en publikation or prisen. Det innovative opstár ofte i mødet mellem andre landes og egne erfaringer, sagde Margrethe Vestager

bl.a. i sin takketale.

En fond oprettes

Pengene skal bruges til en fortsat udvikling af erhvervsuddannelserne. Det er foreslàet, at der oprettes en innovationsfond, som ventes at to gogiske Lærer uddannelse (DEI)

- Vi vil følge den ide, der ligger bag Bertelsmann Prisen. Vi vil statte det formàl, at lærere og skoleledere henter viden hjem fra udlandet. Prisen hylder det at rejse ud og lære konferencer for at reklamere for sig selv og sprede sin egen viden, siger Peter Grürbaum, rektor for DEL, til DTL-nyt.

DEL har stáet for udarbejdelsen af bidraget til messen i Gütersloh. Peter Grünbaum har varet formand for den danske kornmission, der havde representanter for skoleledere organisationer (bl.a. DTL). Undervisningsministeriet og arbeidsmarkedets hjemsted i Danmarks Erhvervspæ

\section{Nu er vi alle verdensmestre}

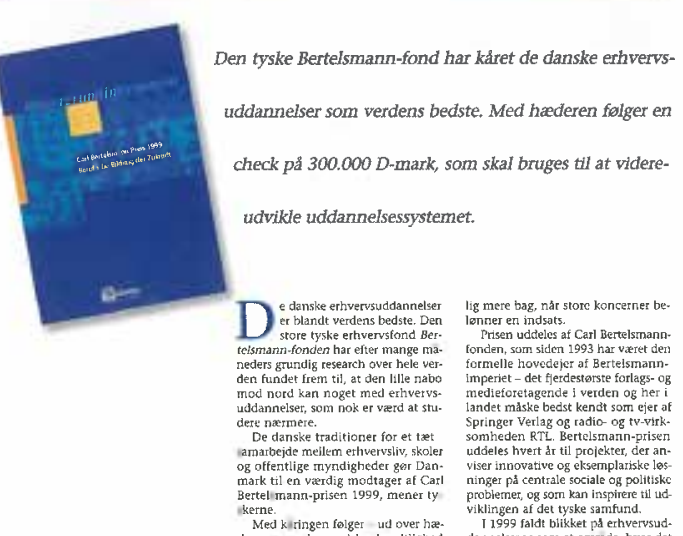




\section{Frem mod målet konkurrencer og mesterskaber}

\section{At opleve mesterskaber i Finland og Canada har givet masser af inspiration til de danske konkur- rencer, hvor også SOSU er med}

Danmarks første fælles mesterskab for erhvervsuddannelser, DM i Skills, var under planlægning, men arrangørerne syntes, de manglede viden, og var meget opsatte på, at konkurrencen skulle blive en succes. Derfor rejste de i foråret 2010 til Finland for at overvære deres nationale mesterskab for erhvervsuddannelser, som er blevet afholdt gennem de seneste 20 år.

Formålet med rejsen var at indsamle inspiration og viden, der kunne bruges i de danske mesterskaber, og overvære, hvordan de i Finland har intensiveret vejledningsindsatsen for afgangseleverne i folkeskolen ift. erhvervsuddannelserne ved at invitere dem med til mesterskaberne. I Danmark var der behov for at skabe interesse for erhvervsuddannelserne og ikke mindst øge tilmeldingstallene.

\section{DM er også branding og vejledning}

Der har i mange år været tradition for at afholde konkurrencer inden for erhvervsuddannelserne i Danmark, men det var først i 2011, at man første gang samlede alle erhvervsuddannelsernes konkurrencer under samme tag i Odense. Behovet for et fælles DM opstod især i kraft af øget interesse for at deltage i det internationale VM i Skills, men også på grund af ønsket om at skabe større interesse for og om erhvervsuddannelserne og kunne vise de unge de valgmuligheder, de har.

- Tidligere har flere enkelte fag haft lokale og regionale konkurrencer - også DM inden for de enkelte fag, men det gav ikke den synlighed, vi ønsker at skabe over for erhvervsuddannelserne, så vi ad den vej også kan være med til at vejlede og sige, der er altså andre veje end det almene gymnasium, forklarer Ulla Groth, projektleder hos Skills Denmark. Hun var en af deltagerne på turen til Finland.

\section{Skills-stafet - en \\ grundskolekonkurrence}

Rejsen til Finland viste især arrangørerne fra Danmark, hvordan man kan intensivere indsatsen for at skabe større interesse for erhvervsuddannelserne hos de unge. I Finland inviterer man afgangselever fra folkeskolen med til mesterskaberne, hvor de får lov til at arbejde med nogle af opgaverne inden for det erhvervsfaglige felt. Det var en idé de danske arrangører tog med sig hjem, da det aldrig før var set i Danmark.

- I Danmark har vi masser af skolekonkurrencer, men det er sådan noget med at skrive det smukkeste digt eller løse det sværeste regnestykke; 
det har aldrig været noget for de drenge og piger med alt for meget krudt i bagen, understreger Ulla Groth og fortæller samtidig, hvad grundskolekonkurrencerne består i:

- Det er nogle små konkurrencer med et meget praktisk islæt, hvor det er tid og rigtigt resultat, der tæller. Det kan være sådan noget som at samle en vandlås eller lave et flisemønster. Det er opgaver, der lægger op til det erhvervsfaglige, men det må på ingen måde kræve, at man har erhvervsfaglig baggrund.

Siden man første gang afholdt grundskolekonkurrence til DM i Skills i 2011, er folkeskolernes interesse for at deltage kun blevet større.

- Nu vil de være med fra Hjørring, Holstebro og Herning. Hele vejen ned gennem Jylland, over Fyn, flere sjællandske byer og de store skoler $i$ København. Alt tyder på, at vi står med succes $i$ hænderne, lyder det begejstret fra Ulla Groth.

\section{SOSU på programmet}

Til DM i Skills i 2011 var det også første gang nogensinde at SOSU-uddannelserne deltog $\mathrm{i}$ en konkurrence inden for deres fag. Indtil da havde det været svært at se, hvordan man skulle kunne konkurrere i pleje og omsorg.

En gruppe lærere fra SOSU C erfarede, at de finske mesterskaber også havde SOSU på programmet, og de tog på eget initiativ til Finland for at se, hvordan det foregik. Det var meget inspirerende, og ambitionen var at få de danske SOSUuddannelser med til World Skills. I 2009 blev World Skills afholdt i Canada, og gruppen søgte derfor legatmidler til at tage derover - også for at mødes med folk fra andre lande, som stod for SOSU-mesterskabet.

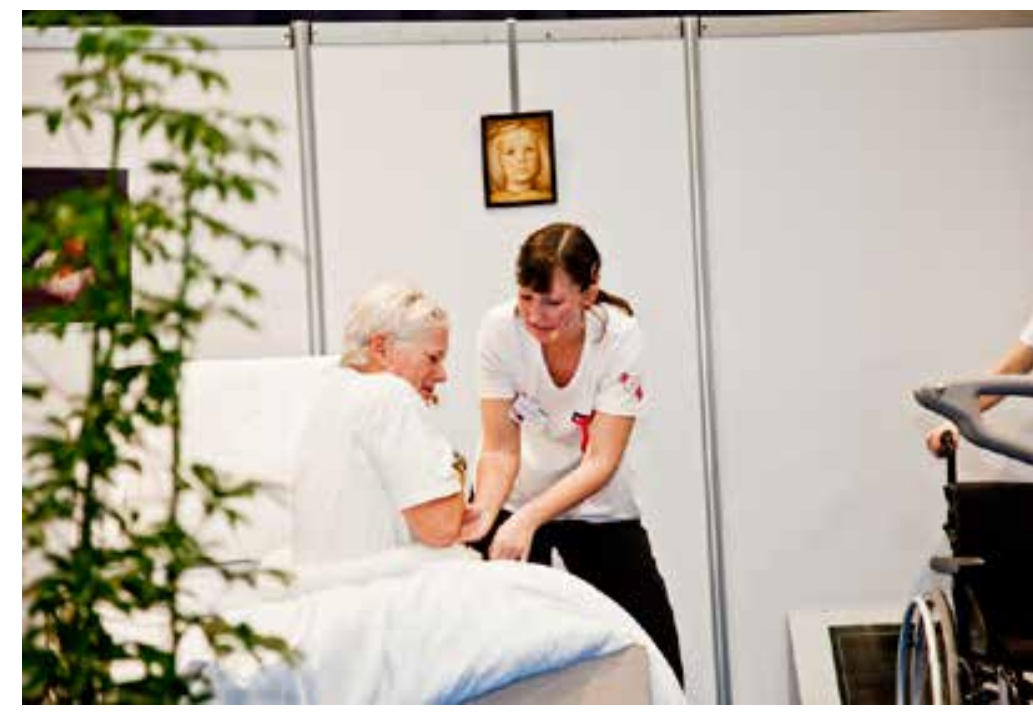

- Det var utroligt inspirerende, og vi fik mange gode ideer til, hvordan vi kunne håndtere det selv. Vi fik også gode kontakter til Skills Denmark, som vi ikke kendte forinden, fortæller Annie Philipsen fra SOSU C, der deltog på turen. De fik også skabt en række kontakter, som de senere har kunnet trække på.

- Vi så med egne øjne, at en konkurrence inden for SOSU-faget sagtens kan lade sig gøre. Vi så, hvor spektakulært det er, og hvor godt det viser kompleksiteten i uddannelsen. Specielt inden for SOSU-faget er der meget tavs viden, og konkurrencen er en måde at italesætte den tavse viden på, uddyber Annie Philipsen.

Hun har efter turen til Canada været med til at udvikle konkurrencemateriale ud fra den viden, de tog med sig hjem, og hun fremhæver, at konkurrencedeltagelse er en stærk motivationsfaktor for eleverne.

- Vi arbejder sammen med de øvrige nordiske lande om at besøge hinandens konkurrencer - og det giver fortsat inspiration, understreger Annie Philipsen. 


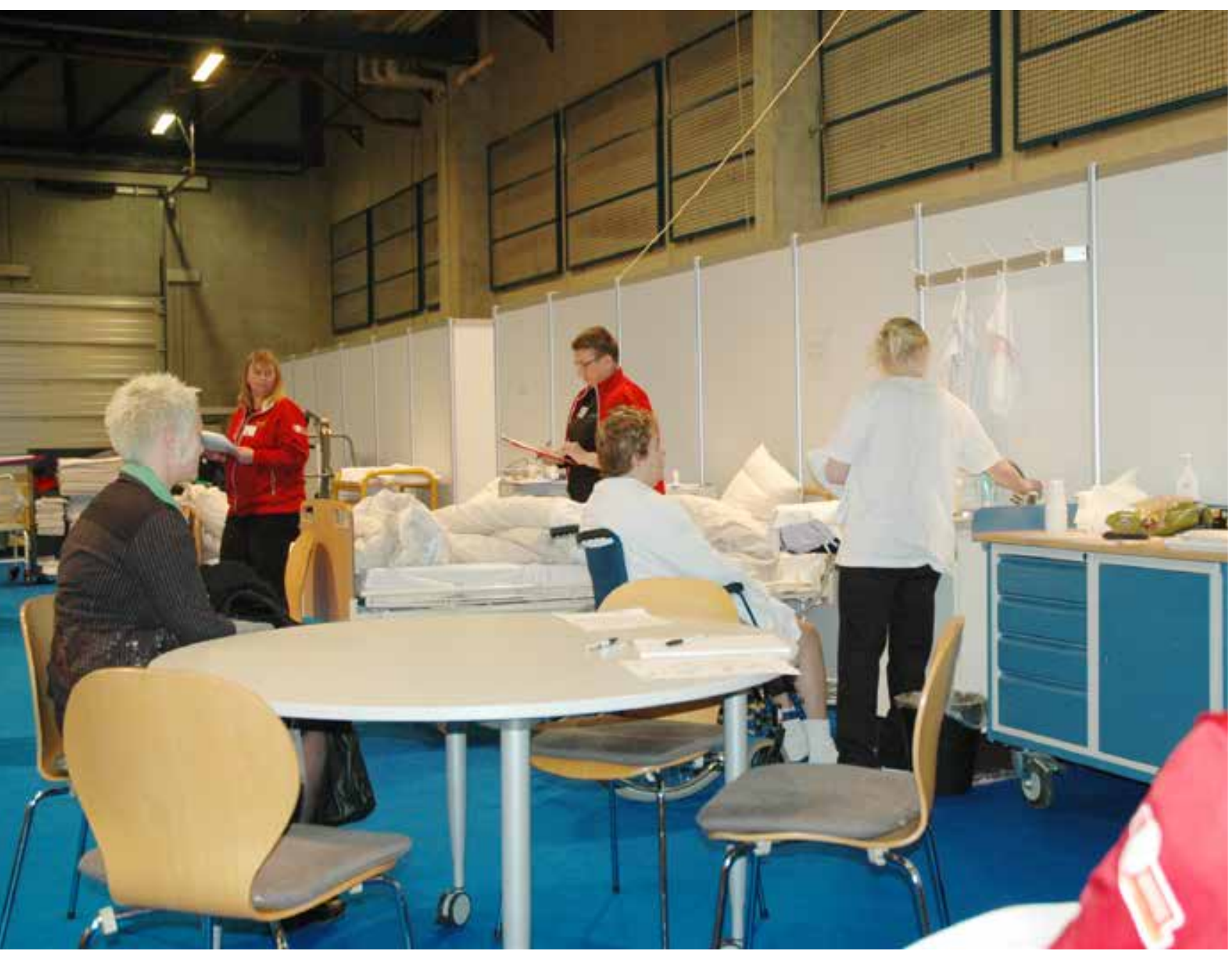

Internationalt netværk og udvikling

For Ulla Groth og Annie Philipsen er der ingen tvivl om, at rejserne til hhv. Finland og Canada har medvirket til, at DM i Skills blev en succes. De erkender begge, at de måske var kommet frem til det samme, hvis de ikke havde været af sted, men det havde taget meget længere tid. Samtidig har rejserne skabt et nyt netværk af kontakter og sparringspartnere, og den øgede deltagelse i World Skills betyder, at Danmark fremover kan være med til at præge indholdet i konkurrencerne og elevernes niveau.

- Hver deltager har sin egen dommerrepræsentant med, der skal bedømme en anden deltager til konkurrencen. På den måde foregår der et indbyrdes afklaringsarbejde mellem dommerne fra de forskellige lande. Og på den måde kan det også 
skabe et godt internationalt netværk på undervisersiden, fortæller Ulla Groth.

Alle SOSU-skoler er nu med til DM i Skills, og selv om SOSU endnu ikke er kommet med til World Skills - primært af økonomiske grunde - så er Annie Philipsen overbevist om, at det nok skal lykkes.

Ulla Groth kan næsten ikke få armene ned over den succes, DM i Skills har oplevet, og hun tror på, at succesen fortsætter: - Vi vil gerne have endnu flere fag med, og så har vi den ambition, at vi skal rundt i landet. Nu har vi kørt de to første i Odense, i Aarhus i 2013, og i 2014 er Aalborg værtsby. Det er tanken, at vi skal rejse rundt med det her fra by til by. Vi kan også se, at tilmeldingstallene stiger, så interessen bliver stadig større.

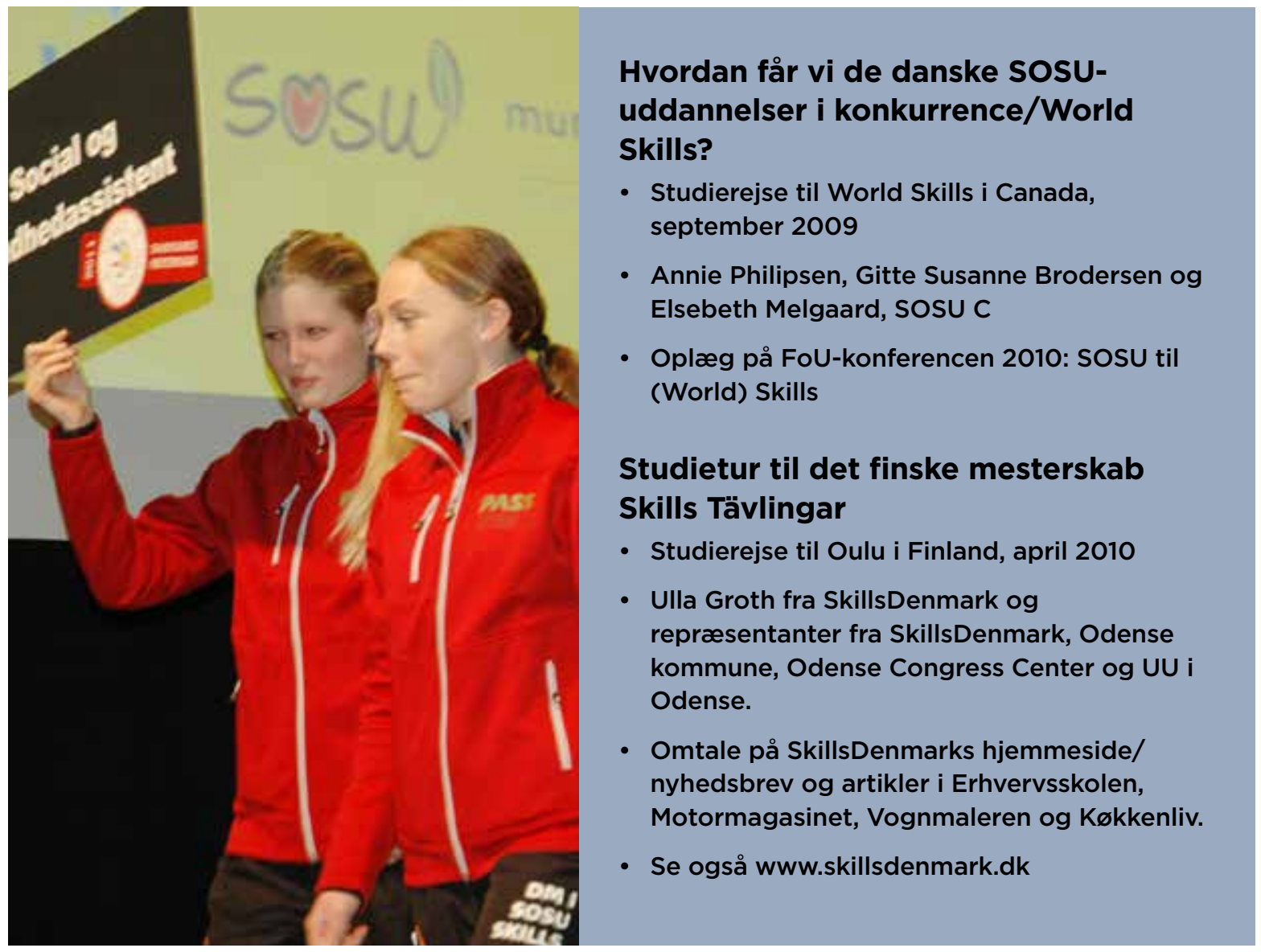




\section{Innovation og entreprenørskab i undervisningen}

\section{Australsk inspiration om brugen af Enterprising Learning}

\section{I foråret 2009 rejste en gruppe fra Århus Købmandsskole til Australi- en for at indhente viden om Enter- prising Learning, en pædagogisk tilgang, der i højere grad sigter mod innovation og kreativitet i un- dervisningen samt et større ejer- skab og ansvar hos eleverne.}

Århus Købmandsskole havde inden studieturen gennem en årrække arbejdet med undervisning $\mathrm{i}$ innovation og entreprenørskab ud fra en praktisk tilgang, der søger at inddrage eksterne interessenter $\mathrm{i}$ forhold til den daglige undervisning. Turen til Australien skulle skaffe ny inspiration og give viden om, hvordan innovation og entreprenørskab kunne blive en større del af uddannelserne i Danmark.

Ny undervisningsform

Projektet udsprang af tanken om, at de internationale samarbejder er stigende, de danske virksomheder får i større grad datterselskaber i andre lande, samtidig med at Danmark får brug for flere, der kan skabe udvikling og vækst i samfundet.

- Skulle entreprenørskab og innovation tages alvorligt, var det nødvendigt at ændre den nuværende praksis, hvor vi gennem stort set hele uddannelsessystemet primært uddanner de unge til fremtidigt lønarbejde. Der skulle skabes en undervisningsform, der udfordrer eleverne til at arbejde innovativt og kreativt, fortæller en af turdeltagerne, Hans Th. Hjorth, fra Århus Købmandsskole. I Australien var man allerede kommet langt med at inkorporere denne tankegang i uddannelserne og undervisningen, og det ville gruppen fra Århus Købmandsskole se nærmere på.

\section{Enterprising Learning}

I Hobart, Tasmanien, mødtes de med Paul Kearney, en førende ekspert inden for Enterprising Learning, der arbejder med undervisning, som er virkelighedsnær og relevant og giver eleverne ansvar for egen læring. Det går i al sin enkelthed ud på, at eleverne får adgang til mere viden, men de skal også selv være aktive i at opsøge den og anvende den kreativt. Undervisningen lægger op til en mere autentisk og problembaseret læring. 
På en skole i Melbourne sender man fx elever ud i op til et års samarbejde med en virksomhed, hvor eleven skal arbejde med specifikke problemstillinger for virksomheden. Her bliver undervisningen meget virkelighedsnær og relevant for eleven. Noget af det samme har de forsøgt at indføre på Århus Købmandsskole, men i et mindre omfang. De har fx samarbejde med en virksomhed, hvor en hel klasse får stillet en opgave fra virksomheden, de skal forsøge at løse bedst muligt.

\section{Virksomhedsprojekter er en succes}

Siden turen til Australien har man på skolen også oprettet en international linje, hvor fx international handel er lagt ind som fag. Og hvor man prøver at få et internationalt islæt i innovation og iværksætteri. Tilsvarende har lærerne bragt international handel ind i engelskundervisningen for bl.a. at få fokus på Australien og dermed gøre undervisningen mere praksisnær.

Gennem faget international handel har skolen haft samarbejde med en større dansk virksomhed, hvor eleverne skulle arbejde med en specifik problemstilling, stillet af virksomheden.

- Det var en kæmpe succes. Det er jo motiverende i sig selv, at de får lov til at lave noget, som ikke er et tænkt projekt, der er lavet af en lærer. Altså ikke en simuleringsopgave, men noget, der er virkeligt, og resultaterne skal til sidst fremlægges for
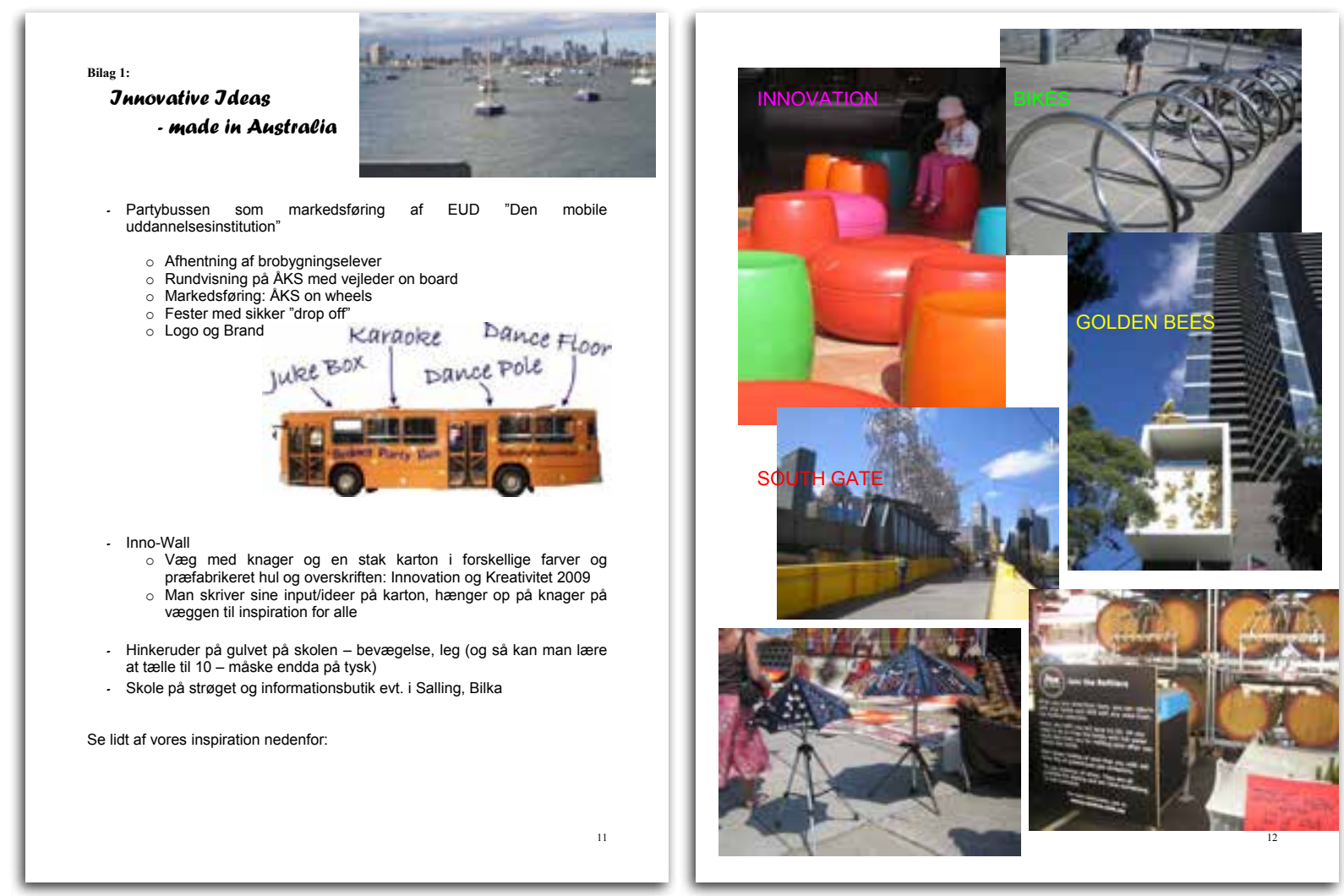
virksomheden. Det var simpelthen så godt et forløb, fortæller Lena Søllingvraa fra Århus Købmandsskole. Hun var i første omgang bekymret for, om det ville blive svært at finde virksomheder, der ville være med i projektet, men bekymringerne blev hurtigt gjort til skamme.

- Man tror, man kommer ud og er til besvær, men det, vi har mødt indtil nu, er faktisk en stor åbenhed fra de virksomheder, vi har kontaktet. Nogle gange tror man, at man skal komme med den færdige løsning. Jeg tænkte faktisk, noget af det, de gjorde i Australien, det får vi aldrig danske virksomheder til, men det gør vi faktisk. Så det kan altså godt lade sig gøre," fortæller Lena Søllingvraa.

\section{HG med udlandsophold}

Skolen har nu også indført, at HG-elever tilbydes op til en måneds udlandsophold i fx Australien. Under opholdet veksler de mellem skoleforløb, hvor de arbejder med australsk marketing og merkantile input, og virksomhedsbesøg. Plus en del kulturelle oplevelser.

- Det har været et fokuspunkt, at eleverne får øjnene op for den måde, man arbejder med iværksætteri på i Australien kontra Danmark. I det hele taget drejer studierejserne sig om at få eleverne ud og gøre dem lidt mere globale. De er jo ikke nødvendigvis så stærke til at komme ud, fortæller Lena Søllingvraa og udtrykker samtidig begejstring over den forandring, eleverne udviser, når de kommer tilbage fra et udlandsophold.

- De elever, der kommer på en måneds ophold i Australien, de kommer hjem som helt andre elever. Der sker noget med dem rent modningsmæssigt. De får sådan et boost, fortæller hun.

\section{Er vi kreative nok?}

Turen til Australien gav input til, hvordan skolen kunne arbejde mere praktisk med entreprenørskab og innovation i undervisningen, og nu tre år efter mener Lena Søllingvraa og Hans Th. Hjorth, at man igen skal se på, hvordan man griber det an - en 360-graders-undersøgelse. Er vi overhovedet kreative nok i vores tilgang? Der er nedsat et arbejdsudvalg, der skal forsøge at redefinere den entreprenørskabstilgang, skolen har.

- Det kræver også, at vi er med på, hvad det vil sige at være innovativ i dag. Det er jo ikke nok, at vi er teoretisk innovative, når vi er en praksisnær uddannelse. Så hvordan er det, vi er innovative, ikke kun $i$ et teoretisk felt, men også i praksis? spørger Lena Søllingvraa.

Et andet initiativ, som måske indirekte stammer fra turen til Australien, er arbejdet med en tvstation på skolen, hvor det er eleverne, der laver programmerne. - Hvordan arbejder vi kreativt med det og skaber noget løss/uppenhed i nogle projekter eller nogle perioder af uddannelserne, hvor det bliver praksisnært? Hvor eleverne faktisk ikke ved, at de arbejder kreativt og innovativt, men i realiteten er det det, de gør i praksis. Alle er meget spændte på resultaterne.

\section{Entreprenørpædagogik og -kapabilitet}

- Studierejse til Australien, februar/marts 2009

- Helene Andersen, Lena Søllingvraa, Jens Kristian Nørgaard Sommer og Hans Th. Hjorth, Århus Købmandsskole

- Rapport: Rapport om Århus Købmandsskoles studiebesøg i Melbourne og Hobart, Australien 2009

- Artikler i Handelsskolen, på EMU.dk og filmklip på YouTube 


\section{God praktik- \\ oplaring i erhvervs- uddannelserne}

\section{- og erfaringer fra den tyske oplæreruddannelse}

Når størstedelen af en dansk erhvervsuddannelse foregår i praktik i en virksomhed, kan der være god grund til at se næermere på kvaliteten af praktikoplæringen. I Tyskland var der inspiration at hente til både god oplæring og kvalificering af de oplæringsansvarlige. Og resultaterne har sat sig spor!

\section{Oplærerkvalificering - den tyske model}

I Tyskland er det lovbestemt, at alle virksomheder, der uddanner elever, skal have kvalificerede oplærere. De følger typisk et kursusforløb, støt- tet af e-læringsværktøjer, og forløbet afsluttes med en certificerende prøve. Formålet med denne kvalificering er ikke alene en certificering, men også at styrke oplærernes sociale kompetencer og deres evne til personaleudvikling og -ledelse. I 2005 tog Regina Lamscheck-Nielsen, dengang ansat i Danmarks Erhvervspædagogiske Læreruddannelse, sammen med repræsentanter fra en række faglige udvalg til Bonn i Tyskland for at undersøge denne oplærerkvalificering nærmere. Fokus lå på indholdet, materialerne og metodikken i uddannelsen til certificeret praktikoplærer af erhvervsuddannelseselever.

- Vi ville gerne have input til god praktikoplæring i Danmark, og det var på det tidspunkt meget underbelyst, fremhæver Regina Lamscheck-Nielsen. Det giver en helt anden praksisforståelse, også for medlemmer af faglige udvalg, der var med, når man ser noget med egne øjne og møder mennesker, der hvor de nu er, og prøver at sætte sig ind $i$ den anden parts logik.

Efter studieturen blev erfaringer og gode råd formidlet via brochurer, der blev igangsat forsøgs- og udviklingsprojekter og resultaterne blev spredt til både virksomhedsledere og andre relevante interessenter på en stor konference på Grundfos under overskriften International ekspertiseudveksling. Her deltog både danske og tyske eksperter.

\section{Deltog i oplæreruddannelse}

I 2007 deltog Regina Lamscheck-Nielsen selv - på en ny legatbevilling - i nogle uger i den tyske oplæreruddannelse. Her kunne hun på nærmeste hold studere uddannelsens indhold, 


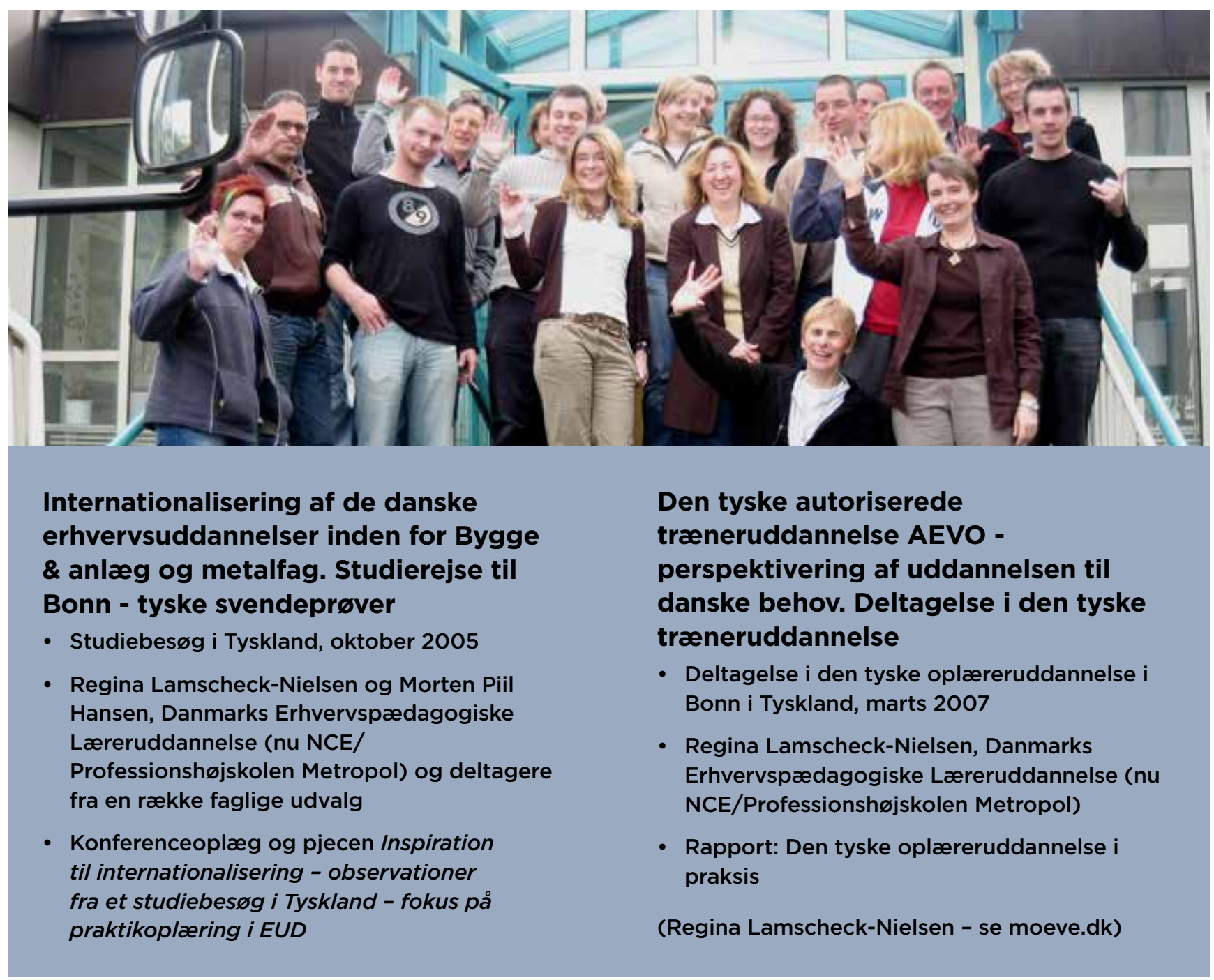

ikke uden videre importere. Og når det gælder Tyskland, så er der mange ting - fx stram styring, et meget hierarkisk system, alt skal formaliseres osv. - som man ikke uden videre kan overføre til Danmark. Her kunne legatet måske med fordel have præciseret i kriterierne, at man skulle reflektere over, hvordan man kan overføre erfaringer, afslutter Regina LamscheckNielsen. 


\section{Mentorordning under udvikling}

\section{En studierejse til Wales inspirerede til en unge- mentorordning på TEC. To af skolens vejledere, som deltog i rejsen, var med i projektet "Relationer, der forpligter", hvor der skulle udvikles forskellige mentor- roller. At ungementorrollen blev en af dem, skyldes i høj grad erfaringerne fra Wales.}

Et øget fokus på fastholdelse af eleverne i erhvervsuddannelserne og elevernes stigende behov for tæt kontakt til en rollemodel fik i 2008 to vejledere fra TEC til at undersøge, hvordan mentorordningen kunne udvikles på skolen. Skolen havde allerede en mentorordning, hvor kontorpersonale, lærere m.fl. var mentorer for eleverne, men det fungerede ikke optimalt, og grænsen mellem at være kontakt- lærer og mentor var svær at finde. En studietur til Wales viste, at mentorrollen indeholder mange aspekter, og at det ikke kun er de voksne, men også unge, der kan fungere som mentorer.

\section{Unge kan hjælpe hinanden}

I Wales oplevede de to vejledere fra TEC, hvor målrettet og aktivt man havde arbejdet med mentorrollen på forskellige niveauer. Især havde de gjort en stor indsats for at fastholde de svagere elever, der havde svært ved det boglige, men måske var gode til det sociale.

- Unge, der var potentielle dropouts, var måske blevet headhuntet af en lærer på skolen, til at man skulle ind i det her mentorprojekt, hvor man over et år var på skole en dag og de andre dage arbejdede med at være mentor for andre elever, fortæller Tina McGhee, den ene af de to vejledere. Hun så straks potentialet $\mathrm{i}$, at de unge kunne være mentorer for hinanden.

- Det var de unge, der fortalte andre unge om stoffer, sex og alverdens ting. De unge taler de unges sprog, og det gør dem mere troværdige over for hinanden, siger Tina McGhee. Hun oplevede, at de unge sagtens kunne hjælpe hinanden og var gode til det. Det krævede bare, at lærerne og skolen gav dem muligheden. Lærerne selv havde været skeptiske i starten og troede ikke, at de unge kunne.

- Men det kunne de jo sagtens, når de fik lov - de kunne faktisk rigtig meget. Det var noget af de vigtigste at tage med hjem, 


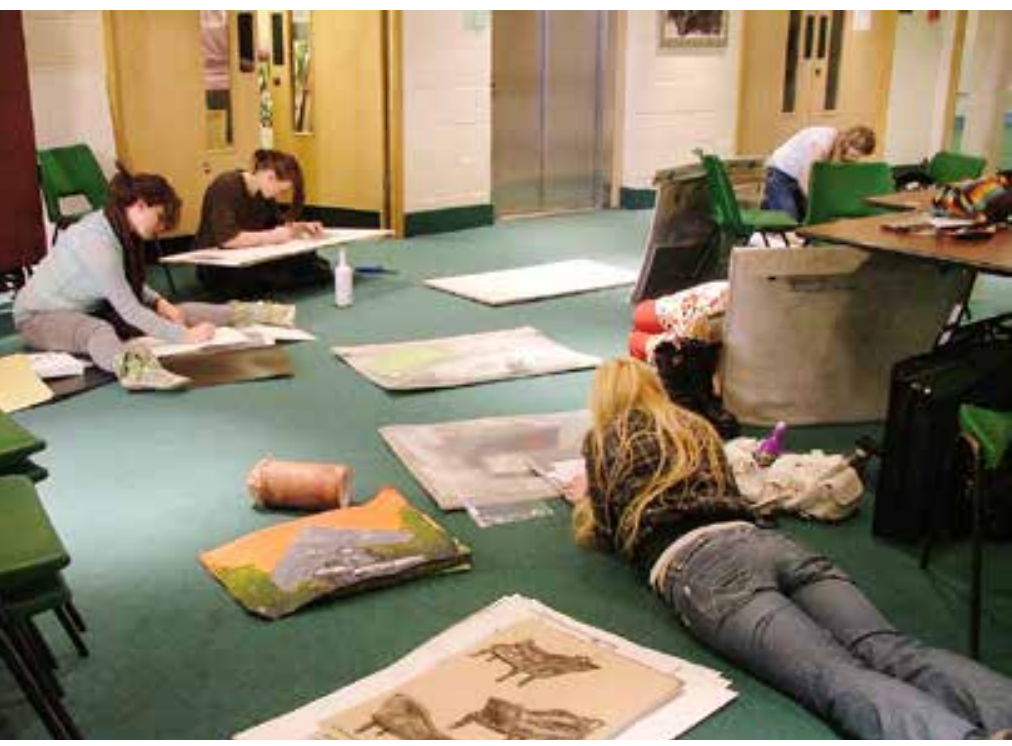

fordi man jo ofte synes, at det skal være voksne, fortæller Tina McGhee.

\section{Ungementorordning på TEC}

I Wales så de eksempler på flere typer ungementorer. Både stærke og svage elever havde fået muligheden, men typisk var det elever, der var længere fremme i uddannelsen, som hjalp en elev, der måske lige var begyndt på skolen. Tilbage i Danmark har de udenlandske erfaringer inspireret, og TEC har arbejdet med at indføre ungementorer på skolen. Som i Wales er mentorerne elever, som er længere fremme i uddannelsen, og de skal agere som en slags buddy for en yngre elev i grundforløbet. Interessen for at blive mentor er vokset.

- Det breder sig som ringe i vandet. I begyndelsen er der ikke så mange, der vil have en mentor, og ikke så mange, der vil være mentor, men efterhånden er det blevet okay at have en mentor og være mentor, understreger Tina McGhee.

\section{En mentoruddannelse måske på trapperne}

Efter at det i 2010 via den såkaldte ungepakke blev bestemt, at alle skoler skal tilbyde en mentorordning, er der kun kommet endnu mere fokus på begrebet. Tina McGhee mener derfor også, at man stadig kan arbejde videre med det, og foreslår selv, at der måske skal til at udvikles en mentoruddannelse for de unge mentorer, der i dag får et diplom på, at de har fået nogle timers introduktion til at være mentor. Ifølge Tina McGhee ville en egentlig mentoruddannelse kunne løfte de unges muligheder senere i deres uddannelsesforløb.

- Hvis du vil være sygeplejerske, politibetjent eller noget andet senere $i$ dit liv, jamen så er det her jo en god start til at prove at have det her ansvar som mentor, fortæller Tina McGhee og siger samtidig, at de stadig koncentrerer sig om fastholdelsen af grundforløbseleverne gennem mentorordningen, så en mentoruddannelse er ikke kommet på tegnebrættet endnu, men ideen fastholdes.

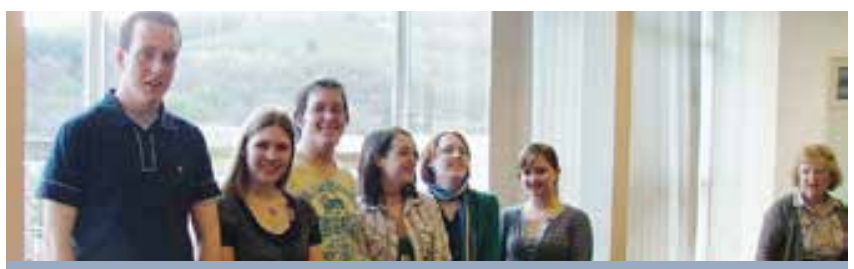

\section{Mentor - en rolle i konstant udvikling}

- Studierejse til Wales, april 2008

- Tina McGhee og Jennifer Mary Lehm, TEC

- Rapport: Mentor - en rolle i udvikling Artikler i Erhvervsskolelæreren og TEC på tryk 


\section{Cooperative Learning - en del af hele skolens tankesat}

Cooperative Learning er en teori, som ikke kun skal anvendes i klasseundervisningen, men bredes ud i hele organisationen. For at blive klogere på Cooperative Learning tog læerere fra Hotel- og Restaurantskolen til Manchester, hvor man i mange år havde arbejdet med det på alle niveauer fra børnehaver til universiteter.

Cooperative Learning er efterhånden blevet en velkendt læringsteori rundt om på de danske skoler, men ideen om at inkorporere teorien som en del af hele skolens tankemønster i forhold til læring og udvikling mangler stadig at blive udfoldet for alvor. Inspiration og erfaringer samlet fra en studierejse til Manchester i 2009 har gjort Hotel- og Restaurantskolen til en af de førende erhvervsskoler i Danmark in- den for brugen af Cooperative Learning $(\mathrm{CL})$ i hele organisationen.

\section{CL i større skala}

Gennem et tidligere forsøgs- og udviklingsprojekt havde projektdeltagerne fået en teoretisk indsigt i CL og erfaringer med brugen af dens værktøjer i praksis. Men de manglede inspiration til, hvordan man kunne sprede det ud til hele skolen, så det ikke var forbeholdt den enkelte lærer i klasserummet, men foregik i et meget større omfang. Man rettede blikket mod Manchester i England, hvor man længe havde arbejdet med $\mathrm{CL}$ og bygget det op helt fra de små klasser.

- Det slog os, hvor udbredt CL var, og hvor meget de samarbejdede om det, hvor struktureret det var sat i gang. Hvordan de havde implementeret det, og hvordan det var lykkedes dem at implementere CL som en del af hele miljøet, fortæller Susanne Poulsen fra Hotel- og Restaurantskolen, som var med i Manchester. Hun oplevede også, at CL kunne anvendes i næsten alle undervisningssammenhænge.

- Det virkede i køkkenet, når de havde madlavning. Inde i kemiog fysiklokalet virkede det, $i$ en dansk- og matematikklasse også. Det gav os den fornemmelse af, at selvfølgelig kan det komme til at fungere hjemme i Danmark også, fortæller Susanne Poulsen og gør samtidig opmærksom på, at succesen $i$ høj grad også skyldtes, at ledelsen bakkede op om projektet.

- Vi så, hvor vigtigt det er, at ledelsen bakker op om det, roser 
Susanne Poulsen ser gerne CL som en del af hele organisationen bliver spredt ud til flere skoler og har derfor også en drøm om, at danske forskere får etableret et projekt, hvor der bliver set objektivt på arbejdet med CL, og forhåbentlig dokumenterer, at det har en effekt. Imens arbejder hun videre med at dele ud af sine erfaringer. Hun arbejder på et projekt om at inddrage CL i arbejdet med gråzonesprog, som hun ser gode muligheder $\mathrm{i}$ at kunne flette sammen til et godt redskab.

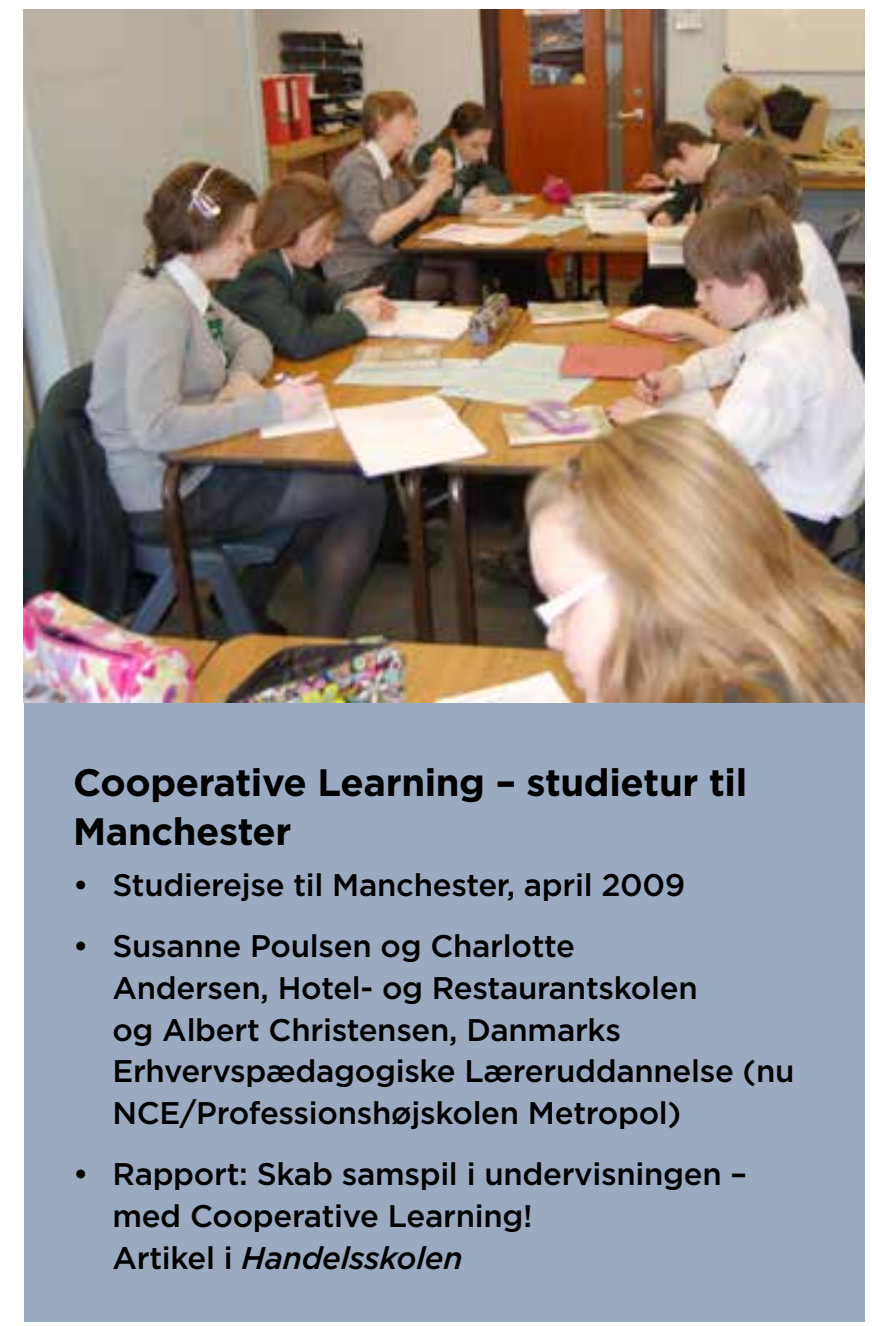

Cooperative Learning er undervisning med samarbejdsmønstre, hvor der ved anvendelse af såkaldte "strukturer" genereres højt avancerede læreprocesser, der bidrager til elevernes faglige, personlige og sociale kompetenceudvikling. 


\section{Den globale praktikplads}

\section{- Inspiration til e-læring fra den australske outback}

Med udsigten til at flere elever ville vælge praktikophold i udlandet, og skolens internationale samarbejde voksede, havde Aalborg Handelsskole et behov for at være gearet til denne udvikling. Derfor lod de sig inspirere af de australske skoler, der på grund af meget store afstande igennem mange år har tilbudt fjernundervisning til deres elever via e-læring.

\section{Behov for globalt miljø}

Med bedre muligheder for at tage praktikophold i udlandet er behovet for et beredskab til fjernundervisning steget, og den fortsatte teknologiske udvikling tilbyder hele tiden ny værktøjer til at arbejde med e-læring. Derfor tog en gruppe fra Aalborg Handelsskole i 2008 til Australien for at høste af skolernes erfaringer der med e-læring og fjernundervisning. Formålet med studieturen var at undersøge, hvordan Aalborg Handelsskole fremover kunne tilbyde PIU-elever i fx Kina, Indien og USA at følge undervisningen via e-læring, og hvordan e-læring kunne supplere den almindelige undervisning på skolen.

\section{E-læring kan ikke erstatte klasserummet}

Udgangspunktet var altså et e-læringsberedskab til PIU-elever (Praktik i Udlandet), men det viste sig, at også mange andre hovedforløbselever kunne have gavn af fjernundervisning. Et års tid efter turen til Australien blev der nedsat nogle lærergrupper for at se på, hvilke muligheder der var inden for de enkelte specialer. - Der er forskel på, om du er butikselev, offentlig elev eller elev i en eksportvirksomhed, der sælger kød til Rusland. Der er meget forskel på de forskellige grupper. Så egentlig gik det ud på, hvor ser vi den bedste effekt af en fjernundervisning på de forskellige specialer? Det gjorde vi så over et stykke tid, hvor hvert speciale - detail, handel og kontor - kom tilbage med nogle forslag til, hvordan vi kunne bruge det på deres speciale. Det er ikke ét, men flere forskellige fjernundervisningskoncepter vi har lavet, fortæller Torben Lindy Christensen. 


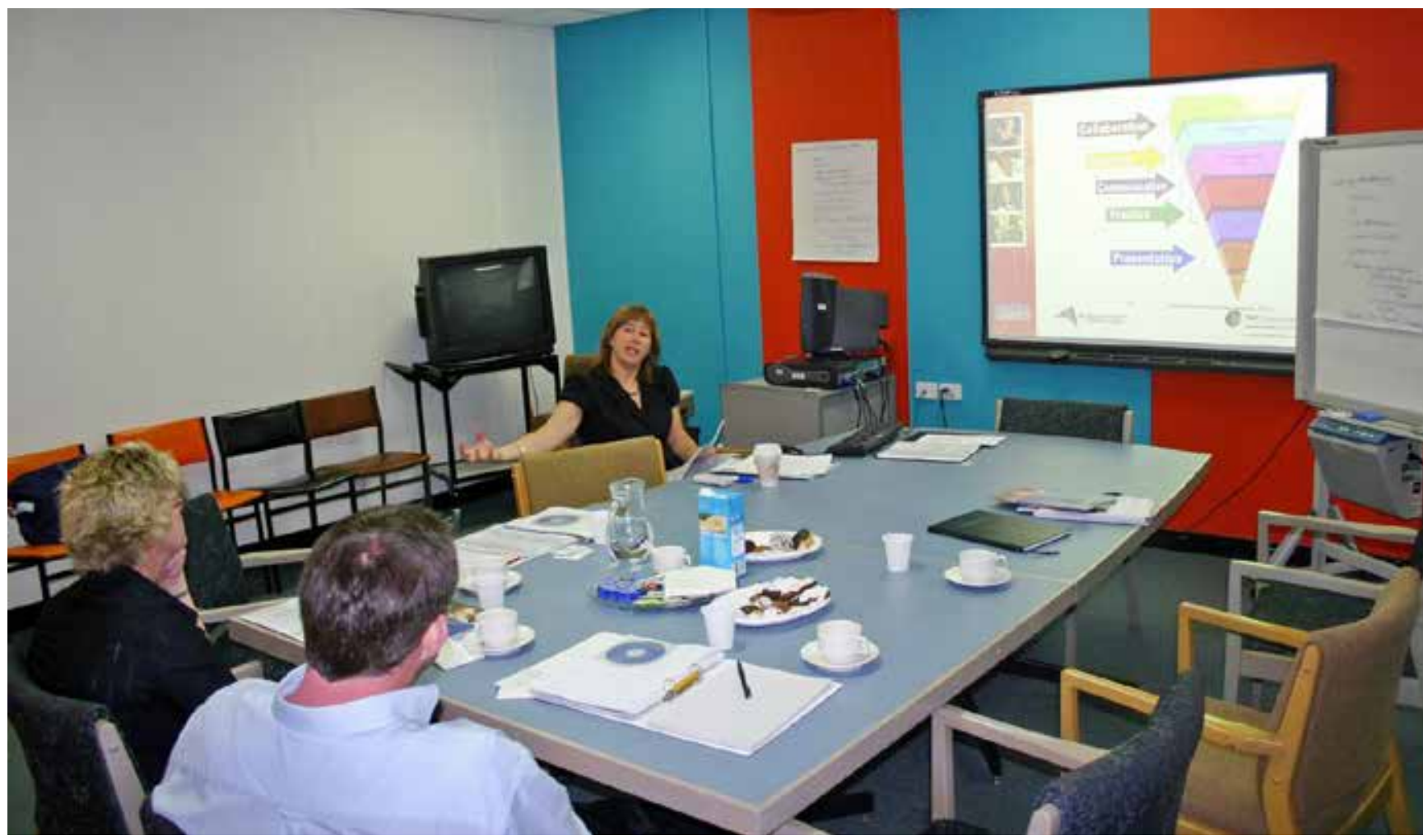

- Der er fjernundervisning på alle specialer i dag, for der kommer jo elever fra København, Sønderjylland, ja mange steder fra, uddyber Torben Lindy Christensen.

På Aalborg Handelsskole tilbyder man i dag eleverne at følge en del af undervisningen via e-læring. Eleverne kan $\mathrm{fx}$ arbejde hjemmefra om mandagen, hvor de inden for normal undervisningstid kan komme i kontakt med en lærer via fx e-mail eller Skype og finde materialer via skolens interne websystem. Det er en løsning for de elever, der kommer langvejs fra, at de ikke skal bruge deres tid på transport den dag.

- For elevernes vedkommende har det været lidt sådan: "Yes, så kan jeg sove længe om freda- gen, så skal jeg ikke op i skole til kl. 8. Men for os gør det jo ingen forskel, om de sover til middag, opgaven skal jo bare afleveres til den tid, den skal afleveres. Og læreren sidder klar ved computeren inden for det tidsrum, der er aftalt. Så hvis eleverne overskrider det, jamen så er der jo ingen hjælp at hente. Så der ligger jo også implicit en vis selvdisciplin $i$ at arbejde under fjernundervisning, forklarer Torben Lindy Christensen.

Skolen tilbyder kun eleverne at arbejde hjemmefra 1-2 dage om ugen, både for at sikre det sociale og fordi arbejdsgiverne helst ser, at eleverne skal møde op på skolen, så man ikke risikerer, at de holder fri i stedet for at arbejde, hvilket Torben Lindy Christensen ser som en udfordring i arbejdet med elæringsbaseret undervisning. 


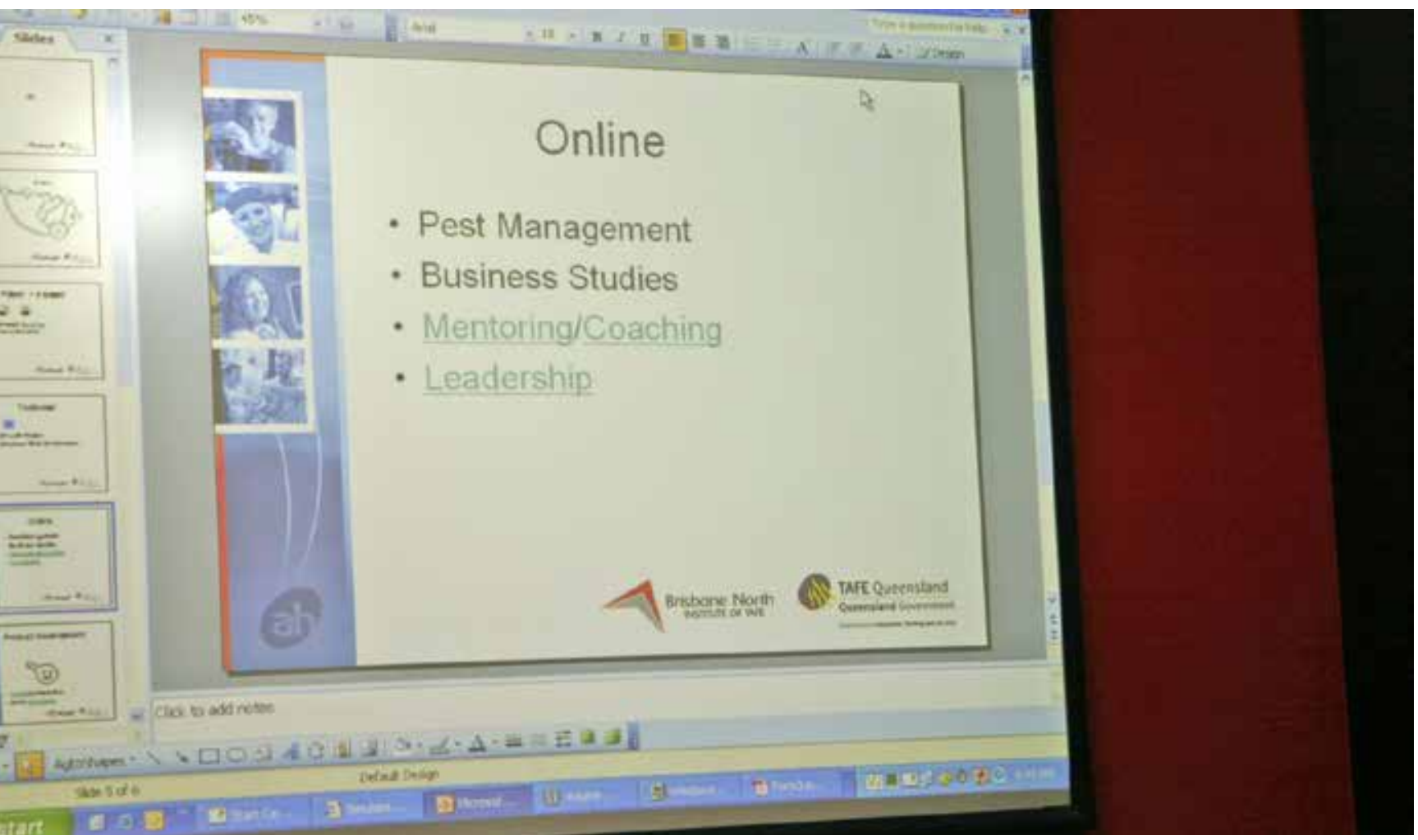

- Den største udfordring for os er den arbejdsgivermodstand, vi møder. Det kan godt være, vi gerne vil være langt fremme i at tilbyde e-læring, men det bliver udfordret af, at arbejdsgiverne trækker $i$ den anden retning, forklarer han. Han pointerer samtidig, at eleverne ofte også har brug for den sociale kontakt, der er i klassen - den kan e-læringen ikke erstatte.

- Vi skal hele tiden være meget opmærksomme på, at det er unge mennesker, vi har med at gøre-det betyder rigtig meget for dem, at de går i en klasse, fortæller han.

\section{E-læringspædagogik}

I Australien fik de også øjnene op for, at e-læring kræver en anderledes pædagogisk tilgang. For det første sidder eleverne foran pc'en i stedet for foran tavlen, og teknologien tilbyder så mange nye muligheder for eleverne, som også lærerne skal forberedes til at bruge, så det præsenteres rigtigt for eleverne. Derfor fik man for et år siden uddannet Danmarks første e-læringspædagog.

- Han er spydspids for at hjælpe sine kollegaer mht. udvikling af e-læringsmateriale og pædagogikken i det hele taget. Han sørger for at hjælpe dem, når de støder på nogle problemer, og også for at undervise dem. Der foregår en stor vidensdeling på vores område. Det, der laves på det ene speciale, kunne godt være interessant for det andet speciale, uden at de egentlig ved, hvad de andre går og laver. Det prøver vi at gøre en del ud af, at de egentlig skal fortælle hinanden, hvordan 
de griber tingene an. Så e-læringspædagogen går ind som specialist og pædagog og siger, det, de gør ovre på det speciale, det gør de, fordi sådan og sådan - og der kan han så være formidleren, afslutter Torben Lindy Christensen.

Torben Lindy Christensen tror på, at skolen inden for en årrække vil få flere elever rundt om i verden, og er derfor tilfreds med, at skolen er gearet til denne udvikling. Han er også godt klar over, at teknologien ændrer sig med lynets hast, så især udviklingen af e-læringsobjekter vil være under konstant udvikling fremover.

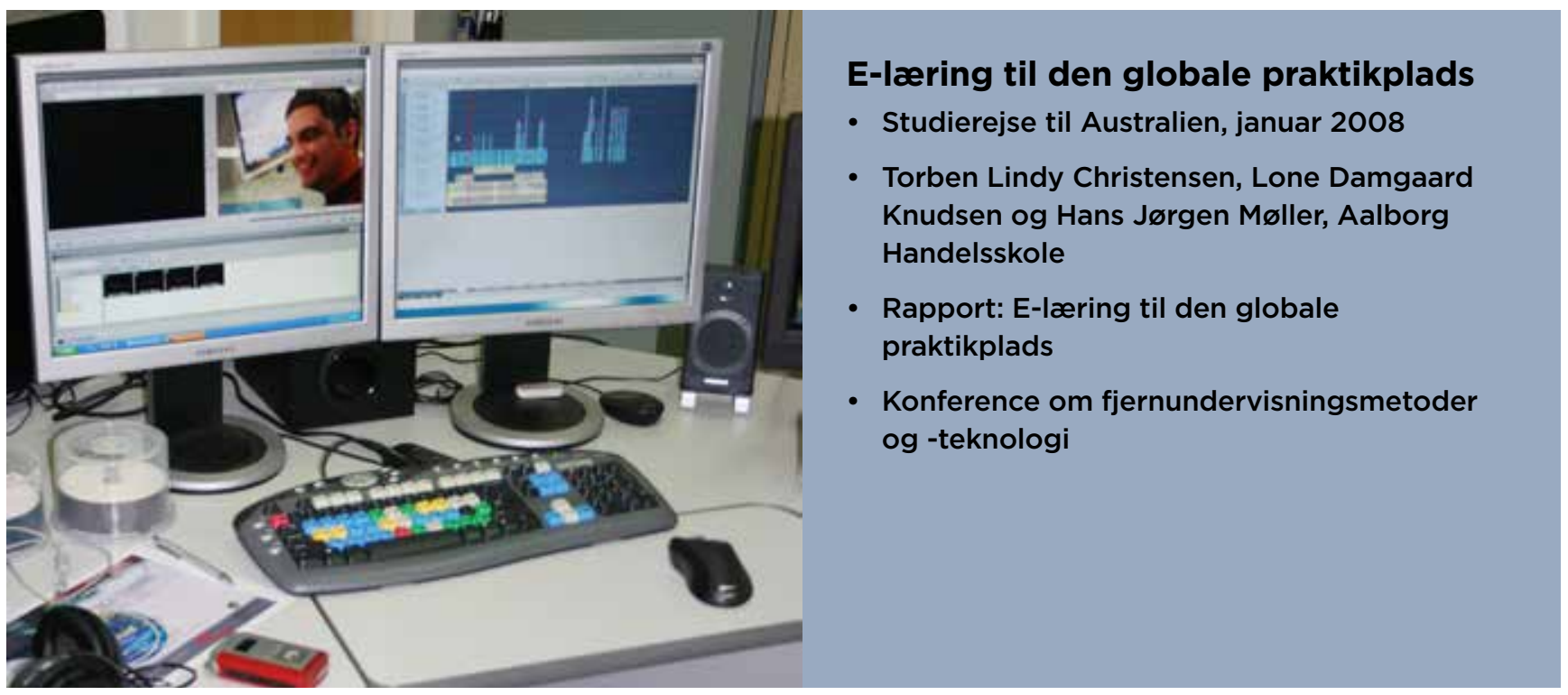




\section{Laringsprocesser i håndvark}

\section{Et kursus i bjæelkehusbyggeri i Ca- nada gav viden og inspiration til undervisningen og samtidig nye perspektiver på, hvordan de unge bliver både bedre til deres hånd- værk og mere motiverede.}

Hvad gør vi, når eleverne synes, undervisningen bliver for teoretisk og abstrakt, og hvordan får vi dem til at engagere sig mere i håndværksfaget? Hvordan får vi en mere praksisnær tilgang til læring? De spørgsmål stillede en gruppe lærere fra træafdelingen på Syddansk Erhvervsskole, da de i 2006 tog til Canada for at følge et kursus i bjælkehusbyggeri på Pat Wolfe Log Building School. De ville gerne komme tættere på en forståelse, af hvad håndværk er, for at kunne definere, hvordan man underviser i det specielt i en skolemæssig sammenhæng.

Hos Pat Wolff fulgte lærerne fra Syddansk Erhvervsskole et kursus $\mathrm{i}$ at bygge et bjælkehus fra bunden: find nogle store træer, fæld dem, læg stammerne oven på hinanden og du har et hus. Pat Wolfe's metoder smittede meget af på gruppen, da de blev fascineret af hans måde at inddrage deltagerne på, arbejde med materialer og værktøj, være sammen med kursisterne i arbejdet og ikke bare være en underviser.

Man vil måske synes, at bjælkehusbyggeri i Canada ligger langt væk fra det, de danske håndværkselever skal arbejde med i praksis, men ifølge Mogens Victor Andersen, projektleder og en af deltagerne på studieturen til Canada, har vi meget at lære af en mand som Pat Wolfe og hans metoder.

- Det giver et meget godt spejlbillede af det, vi selv gør. At vi ikke nødvendigvis er de bedste eller har monopol på de bedste metoder. Det betyder, at man får indsigt $i$, hvad kultur, frihed, tænkemåder, samarbejde og ansvarlighed betyder for resultaterne, fortæller han.

\section{Fornemmelse for materialerne}

Det specielle ved bjælkehusbyggeri er, at det kræver et stort materialekendskab, der bestemmer, hvordan de enkelte stammer udvælges, og hvordan samlingerne kommer til at passe sammen. Dette materialekendskab synes Mogens Victor Andersen godt, der kunne arbejdes mere med i faget i Danmark.

- Jeg siger nogle gange, at sådan nogle tømrerelever, de skulle have en planke liggende i deres seng hele deres læretid. Egentlig bare som et billede på, at de skal have fat i materialerne, de skal meget tydeligt fornemme, hvad det er, fortæller han. 


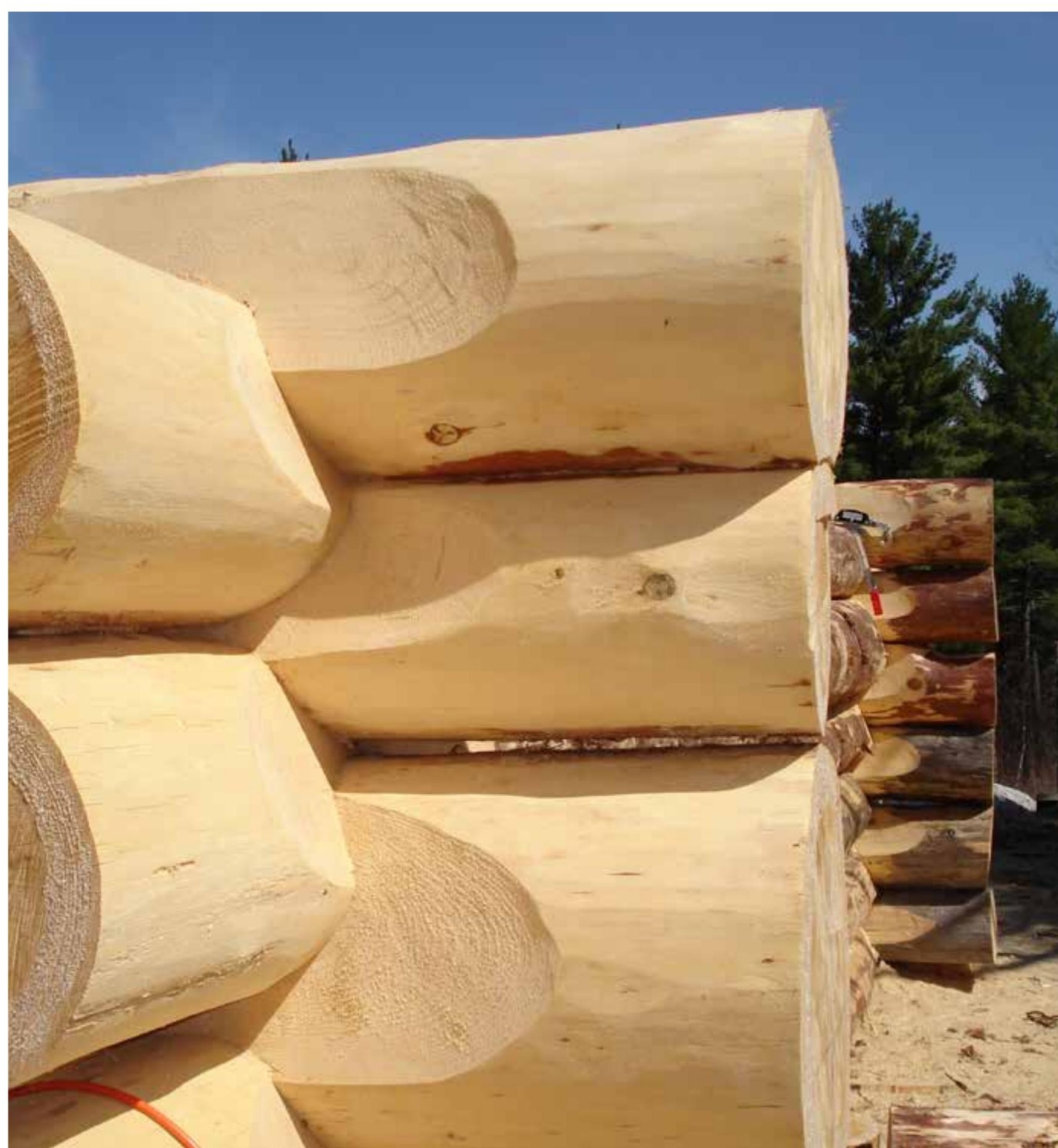




\section{Læreren skal ikke kun være instruktør}

Under opholdet i Canada blev Mogens Victor Andersen og resten af gruppen især opmærksomme på, hvordan Pat Wolfe ikke blot var en underviser, men også tog del i arbejdet med bjælkehuset på lige fod med de andre.

- Undervisning i praktik og håndværk foregår bedst gennem en mesterlæreagtig proces. At man som underviser laver tingene sammen med eleverne. At de gennem den proces ser fagmandens ageren, begejstring og professionelle metodik og prøver at imitere den. Det synes også at være en måde, hvor eleverne får oplevelsen af at være aktøren, uddyber Mogens Victor Andersen.

\section{Et oplæringssted, ikke en skole}

På Pat Wolfe's skole blev gruppen fra Syddansk Erhvervsskole konfronteret med en helt anden type elever og en anden undervisningsform, som ikke var styret af institutionelle forhold som det danske. Det satte gang i en masse refleksioner om, hvordan de daglige undervisningsformer og oplæringsmønstre kunne udforskes og gøres mere praksisnære og frie.

For Pat Wolfe var det vigtigt at understrege, at skolen ikke var en skole, men et oplæringssted, hvor man kan komme og lære sig et håndværk.

- Det handler om, at håndværket bliver så tæt på den enkelte som muligt eller nærmest en forlængelse af ens bevidsthed og ikke noget, man bare laver fra kl. 7 til kl. 15, understreger Mogens Victor Andersen. Han har siden turen arbejdet med, hvordan man trods de rammer, det danske skolesystem giver, kan nærme sig en situation, som minder om den hos Pat Wolfe.

Han har fx indført, at hans undervisning i samfundsfag er samlet på heldagslektioner, så eleverne har samfundsfag en hel dag i otte timer. Hans synes, at de tidligere korte lektioner ofte gik med for megen snak, kiggen på uret og konstatering af, at der snart var pause, og så kunne man ikke rigtig nå at komme i gang alligevel. Både elever og lærere var bekymrede
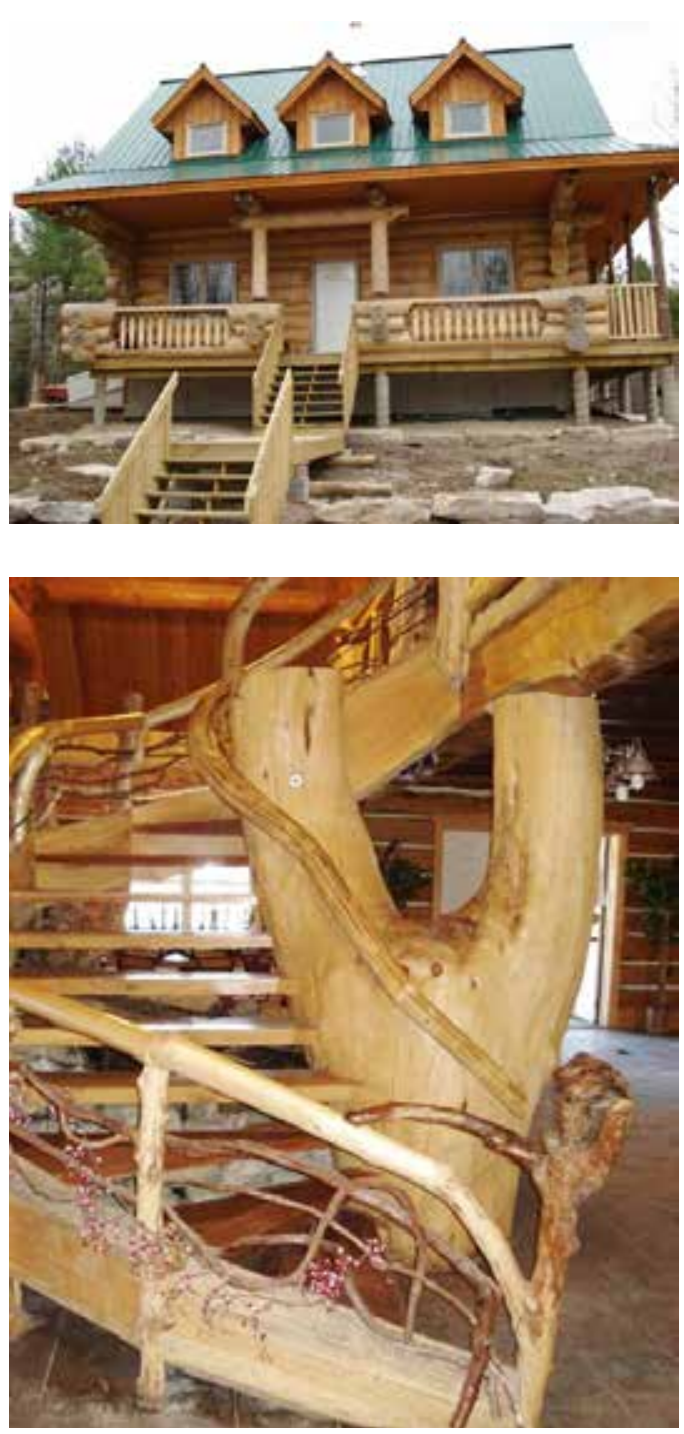
for, at en heldagslektion ville blive for meget for eleverne, men det var netop Mogens Victors udgangspunkt. - Nogle sagde, at de blev helt krollede, men ja, så lad dem blive krøllede. Det er kun, hvis de bliver krøllede, at der sker noget, påpeger han og uddyber også vigtigheden af lærerens engagement og lyst til at eksperimentere med faget sammen med eleverne, da det også skaber læring for eleverne.

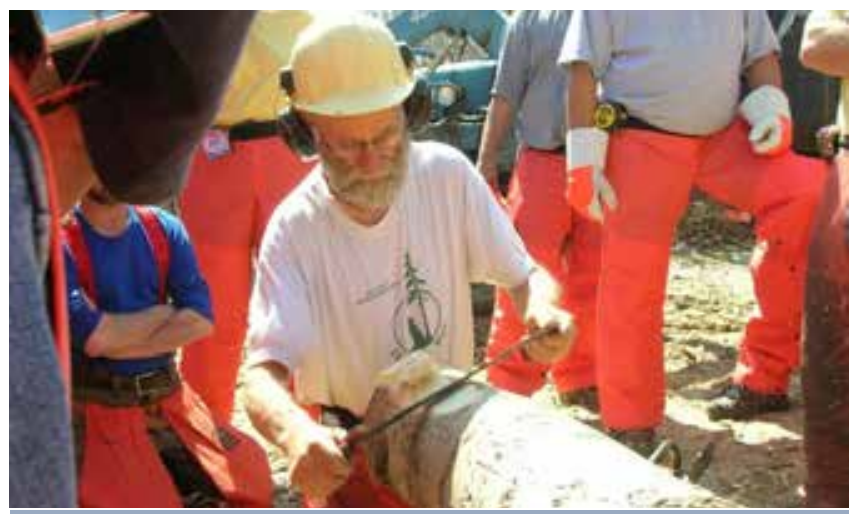

Læringsprocesser i håndværk kompetenceudvikling i træhusbyggeri

- Studierejse til Canada, april 2006

- Mogens Victor Andersen, Steen Andersen og Niels Kastberg Nielsen, Odense Tekniske Skole (nu Syddansk Erhvervsskole)

- Rapport om håndværksoplæring - baseret på studier af håndværksprocesser, blandt andet gennem studierejse til Canada

- Kronik i Fyens Stiftstidende, temadag på skolen og artikel i TIB-bladet

(The Pat Wolfe Log Building School - se http://www.logbuildingschool.net/)
- Det kræver, at du som underviser vil bryde nogle af dine grænser. At du også godt tør træde ved siden af, at du også tør lave noget, som ikke fungerer. Vi skal gå ud og gøre tingene sammen med eleverne. Og de mærker, at det også er i orden at blive træt, for nu har vi også knoklet. Så tror jeg faktisk, det giver et engagement. - Hvis man vil arbejde med at have med andres fremtid at gøre, så må man være villig til at ofre lidt af sig selv også, understreger Mogens Victor Andersen.

- Eleverne bliver mere engagerede. Vi synes, vi kan mærke en forskel. Nogle af lærerne tænker lidt mere over det med at arbejde sammen med eleverne frem for bare at være underviser og instruktør, afslutter Mogens Victor Andersen. 


\section{Kreativitet, innovation og ivarksatterkultur}

\section{Opgaven var klar: En større sats- ning på innovation, kreativitet og iværksætteri i de danske erhvervs- uddannelser. Massachusetts, USA, blev stedet, hvor en bredt sam- mensat gruppe fra erhvervsud- dannelsessektoren i 2007 hentede brugbar viden hjem til Danmark.}

- I USA tænker man, at det er helt i orden at bygge slotte i luften, bare man på et tidspunkt husker at sætte fundament under. I Danmark tænker vi nedefra og op. Det var en meget klar forskel, fortæller fagkonsulent Steen Forsmann, Ministeriet for Børn og Undervisning (nu Undervisningsministeriet). Han var en af de fem deltagere på USA-turen, som skulle give inspiration til det ministerielle udviklingsprogram om innovation og iværksætteri i erhvervsuddannelserne.

\section{På jagt efter innovations- og iværksætterikultur}

Babson College i Boston, Massachusetts, har internationalt et godt ry, når det gælder udvikling af entrepreneurshipkompetencer, og projektdeltagerne blev heller ikke skuffede, da de besøgte skolen tilbage i efteråret 2007 for at hente inspiration til, hvordan man kunne fremme innovations- og iværksætterikulturen i de danske erhvervsuddannelser.

På Babson College det blev tydeligt, i hvor stor skala skolen arbejder med iværksætteri. - Det særlige var, at virksomhederne var så tæt knyttet til skolen og gav eleverne autentiske problemstillinger og cases at arbejde med, fortæller Dorrit Sørensen, som deltog fra DEL (Danmarks Erhvervspædagogiske Læreruddannelse - nu NCE/Professionshøjskolen Metropol). Mange af skolens undervisere og vejledere var succesrige iværksættere med flair for pædagogik. Det blev tydeligt, hvordan autentiske entrepreneurshipforløb kan tænkes ind i skolesammenhæng og motivere eleverne til at eksperimentere og bryde rammer. - De unge var oprigtigt engagerede, fordi de fik projekterne selv og oplevede sig selv som iværksættere. De var også gode til at performe og til at få feedback fra de andre elever, uddyber Dorrit Sørensen. Samtidig var det betydningsfuldt, at virksomhederne, altså aftagerne af de uddannede elever, havde indflydelse på og føling med elevernes uddannelse.

Set i bakspejlet er det blevet tydeligt, hvor meget det processuelle betyder. - I Danmark er vi vant til at fremlægge og vurdere vores slutprodukt. Det, der sprang i øjnene på Babson, når de arbejdede 


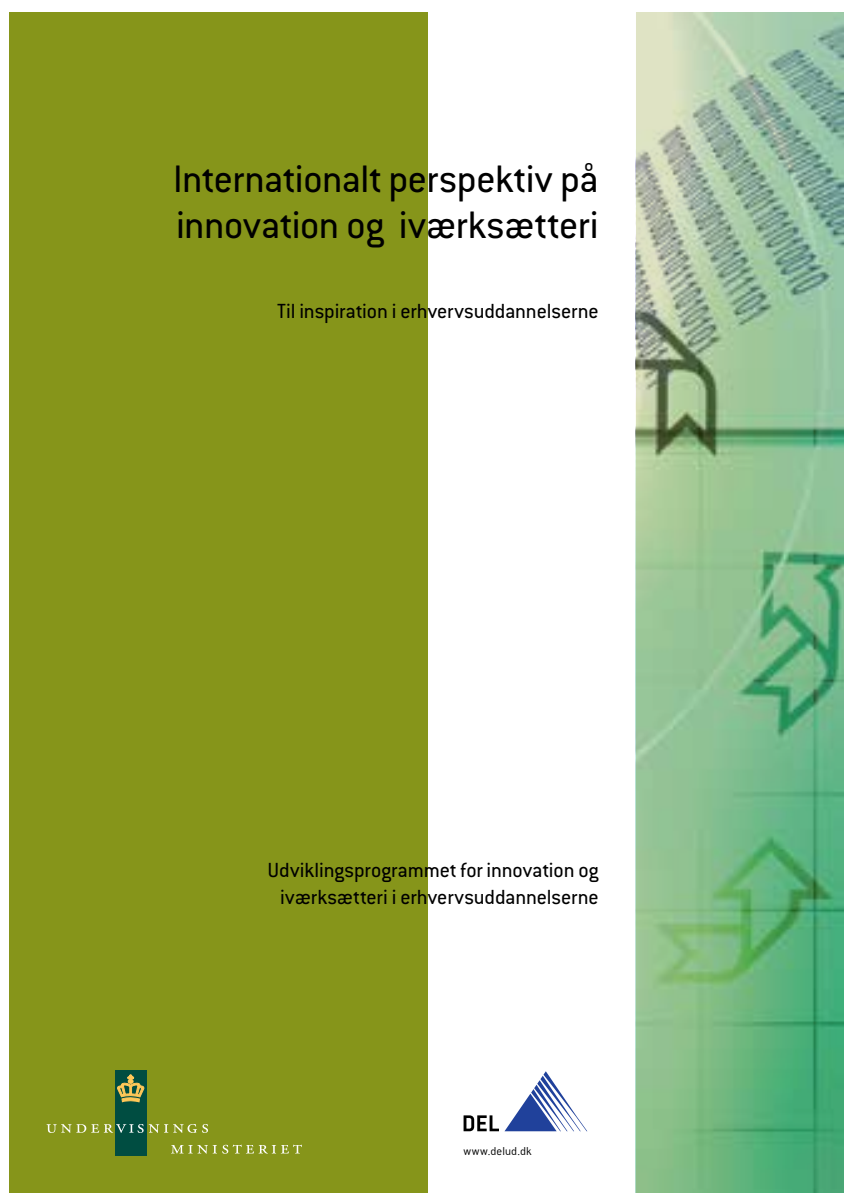

med innovation, var, at de turde være "undervejs". At nå noget unikt, en værdiskabende forandring, kræver meget opmærksomhed på processen, og det skal pædagogikken i høj grad tage højde for, tilføjer Dorrit Sørensen.

Gruppen besøgte også Springfield Technical Community College, som minder mest om de danske erhvervsuddannelser. Også her arbejder man dedikeret med iværksætteri og innovation, og der bliver gjort alt for at fremhæve talent og succes. - På bedste amerikanske vis blev de unges succes synliggjort ved, at der fx blev hængt billeder og beviser op, en meget åben fremvisning af det at være et talent. Og ikke nødvendigvis bogligt eller teoretisk, som vi er vant til i Danmark, og hvor det udløser høje karakterer, men derimod et talent til at skabe noget. Det inspirerede os til en anderledes kompetencetænkning, hvor vi ikke bare skal stå og servere teori hele tiden og så tro, at lærerne og eleverne selv kan lave den transformation til praksis - vi bliver nødt til at udvikle nogle helt anderledes projekttyper, som har et andet DNA, og som giver denne her visualisering af kompetencen, understreger Dorrit Sørensen.

En anden ting, som gjorde Springfield interessant, var deres fantastiske inkubatormiljø, hvor eleverne kunne udvikle en virksomhedsidé og opbygge en virksomhed, som om det var en "rigtig" virksomhed, dvs. meget autentisk, selv om det var i det studiemiljø. - For eksempel havde de et samarbejde med universiteterne, sådan at de, der læste til advokat, kunne give juridisk bistand. Det er udviklende for begge parter og er med til at nedbryde institutionelle grænser, som ofte er hindrende for en innovativ tilgang, fortæller Dorrit Sørensen.

\section{Mod en fælles begrebsforståelse}

Baggrunden for studierejsen var som nævnt, at der skulle iværksættes et udviklingsprogram, som skulle belyse og komme med forslag til, hvordan innovation og entreprenørskab i højere grad kunne inddrages i erhvervsuddannelserne. DEL skulle i et særligt projekt dokumentere relevant viden og komme med ideer og forslag. Det var derfor oplagt at inddrage internationale erfaringer, og med legatmidlerne blev det muligt at samle en gruppe med repræsentanter fra ministerium, skoler og DEL, som sikrede en bredde og systemforankring på studieturen til USA. - Vi havde brug for at diskutere best practice og den nye viden på tværs, og vi vidste, at vi skulle bruge det fra hver vores platform, når vi kom hjem, siger Steen Forsmann.

Besøgene, som også omfattede MIT (Massachusetts Institute of Technology), skærpede deltagernes bevidsthed om, at selve begrebet innovation krævede en afklaring hjemme i Danmark. Hvis man ville arbejde med innovation og iværksætteri i det 
danske system, skulle interessenterne have en større forståelse af, hvad begrebet indeholder. Der blev derfor arrangeret flere seminarer, hvor bl.a. en professor fra MIT holdt oplæg, og hvor en større kreds af embedsmænd var inviteret med.

- Vi ønskede at få skabt en fælles kulturel forståelse af, hvad begreberne innovation og iværksætteri betyder. Det handler om hele tiden at få sat nogle rammer og ord på, så alle kunne deltage i en mere kvalificeret diskussion om udviklingen af erhvervsuddannelserne. Vi brugte det til intern træning af ministeriets egne folk, fortæller Steen Forsmann.

\section{Turde springe ud i det}

Deltagerne kom hjem med en rygsæk fyldt med ideer til at implementere en større grad af innovation og iværksætteri i de danske erhvervsuddannelser. Legatet var med til at sikre, at relevant international viden blev hentet hjem. Den viden blev efterfølgende omsat i lovgivning, i læreruddannelsen og formidlet til skoler, faglige udvalg og andre interessenter i kraft af projekter, artikler, oplæg på konferencer og seminarer mv. - Der blev oprettet netværk, vi udviklede pioneruddannelsen - en innovationsuddannelse - og kurser i innovationsledelse, og USA-turen har da helt sikkert også inspireret til det igangværende Uddannelseslaboratorium (UddX), et regionsprojekt, der eksperimenterer for at nytænke og udfordre erhvervsrettede uddannelser, uddyber Dorrit Sørensen, som nu er chef for Uddannelseslaboratoriet.

- Vi kom hjem med en forhåbning om, at vi i Danmark kunne lære af den amerikanske tankegang om at turde springe ud $i$ projekterne, hvor vi måske i Danmark er lidt for berøringsangste. Man er kommet noget af vejen, men det er en kæmpe opgave, fremhæver Steen Forsmann, og Dorrit Sørensen tilføjer: I USA fik vi i den grad inspiration til at tæenke ud af boksen, til helt nye vinkler på den måde, vi tænker uddannelse på.

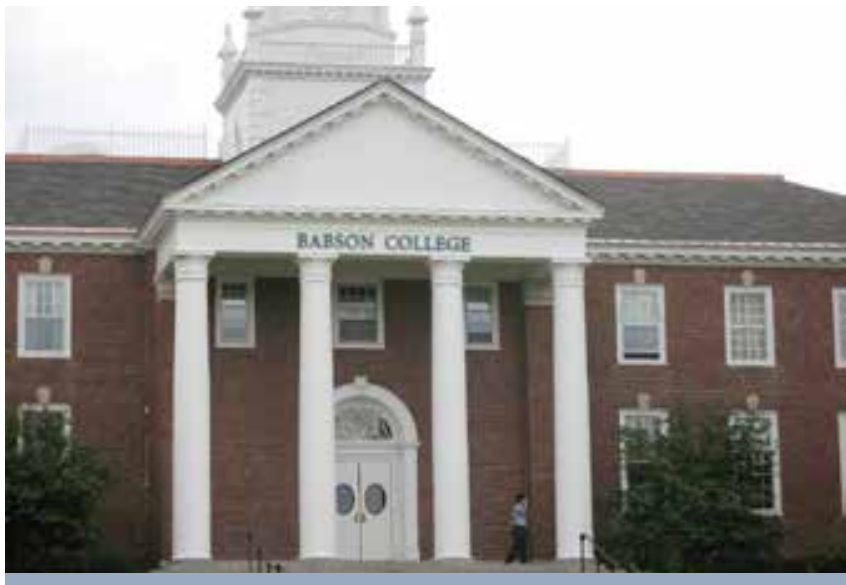

\section{Inspiration til udviklingsprogrammet Innovation og iværksætteri i EUD}

- Studierejse til Massachusetts, USA, oktober 2007

- Dorrit Sørensen, Jens Aaslyng Dall, Rasmus Frimodt fra Danmarks Erhvervspædagogiske Læreruddannelse (nu NCE/Professionshøjskolen Metropol), Dorte Bjerregaard, EUC Nordvestsjælland og Steen Forsmann, Ministeriet for Børn og Undervisning (nu Undervisningsministeriet) og Roskilde Tekniske Skole

- Rapport: Inspiration til udviklingsprogrammet Innovation og iværksætteri i EUD. Rejse til Massachusetts og Boston, oktober 2007

- Oplæg på FoU-konference, kurser, seminarer og uddannelser.

Se også Det erhvervsrettede uddannelseslaboratorium, http://uddannelseslaboratoriet.dk/ 


\section{Udenlandske erhvervsuddannelser under lup}

\section{Danmark har et af de bed- ste erhvervsuddannelsessy- stemer i verden, men vi kan stadig lære nyt af andre lande}

- Selv om vi har fået prisen for at have verdens bedste erhvervsuddannelser, så er der jo ingen grund til at hvile på laurbærrene. Der var måske nogle lande, der var næsten lige så gode, som bare ikke vandt, fortæller Benny Wielandt, vejleder på TEC Gladsaxe.

Han har som den eneste fået bevilget et legat hele syv gange. Han har rejst til de baltiske lande, Ungarn, Rumænien, Polen, Tjekkiet, Slovakiet, Irland og Australien. Hans udgangspunkt har været at undersøge og formidle i værtslandene, hvad det er, der har gjort den danske EUD-uddannelsesmodel så god, at den fortjente en pris, men også hvordan vi fortsat kan udvikle uddannelserne, og om der mon ikke også er noget, vi kan lære af andre lande.

- Jeg har ikke set nogle erhvervsuddannelser undervejs, der er bedre end de danske, men jeg har set nogle, der matcher os. Så vi skal være glade for, at vi vandt prisen, og at den gav os mulighed for at komme ud og se andre landes erhvervsuddannelser og måden, de griber det an på, erklærer Benny Wielandt.

\section{Omvendt og anderledes erhvervsuddannelse}

Benny Wielandt vil især fremhæve de tidligere østbloklande, som han mener er nået langt i udviklingen af deres erhvervsuddannelsessystemer, men har løst det på en anden måde, end vi har. Her har de ingen kontraktbaserede lærlingeuddannelser som i Danmark, hvor det meste af uddannelsen foregår i praktikvirksomheden. De har et skolebaseret system med indlagt praktik, hvor de unge i 3-4-årig EUD hvert år er 10 måneder på skole (teori og praktik) og to måneder i virksomhedspraktik.

- Eleverne får ikke løn, da de ikke er i lære, men praktikstederne er altid villige til at lægge hus til de her praktikperioder, for de bruger det til at rekruttere de bedste elever. De bedste fär meget hurtigt arbejde efter praktikken, fortæller Benny Wielandt.

En anden forskel fra det danske system, som rejsen til Tjekkiet og Slovakiet synliggjorde, er, at de erhvervsfaglige og de erhvervsgymnasiale uddannelser typisk ligger i samme bygning, og eleverne deler lokaler og kantine, så der ikke opstår det skel mellem uddannelserne, som vi kender det i Danmark. - Erhvervsuddannelseseleverne er jo på skolen hele tiden. Er man dygtig nok, kan man flytte fra erhvervsuddannelsessporet til gymnasiesporet, og det er også muligt at flytte den anden vej, uddyber Benny Wielandt. 
hvad eleven skal kunne, i nogle kompetencemål, og så går man bagefter ind og beskriver de enkelte kompetencer, og hvad man skal kunne (learning outcomes), men man går ikke ind og beskriver, at eleven skal have så og så mange timer i det. Det er en helt anden tilgang til uddannelserne, fortæller Benny Wielandt, der efter hjemkomsten blev inviteret ind i Undervisningsministeriet for at fremlægge sine erfaringer med det australske, kompetencebaserede system til at inspirere ministeriets arbejde med fremtidens erhvervsuddannelser.

Benny Wielandt synes stadig, der er meget, vi kan lære af andre lande, og som de andre kan lære af Danmark. Han oplevede fx, at specielt australierne var meget begejstrede for, at vi i dansk EUD også rummer fag som miljø og samfundsfag. Vi betragter jo erhvervsuddannelserne også som ungdomsuddannelser. Dermed påtager vi os samtidig at uddanne eleverne ikke bare til et erhverv, men også til at være borgere og til at lære hele livet.

\section{Behov for vidensdeling}

Benny Wielandt synes, det har været spændende og lærerigt at se og opleve de mange forskellige uddannelsessystemer, og han har været meget aktiv med at sprede den viden, han har hentet hjem. - Der er i den grad brug for mere vidensdeling på tværs af landene, og det kunne være godt med en database, hvor erfaringer blev samlet, understreger Benny Wielandt.
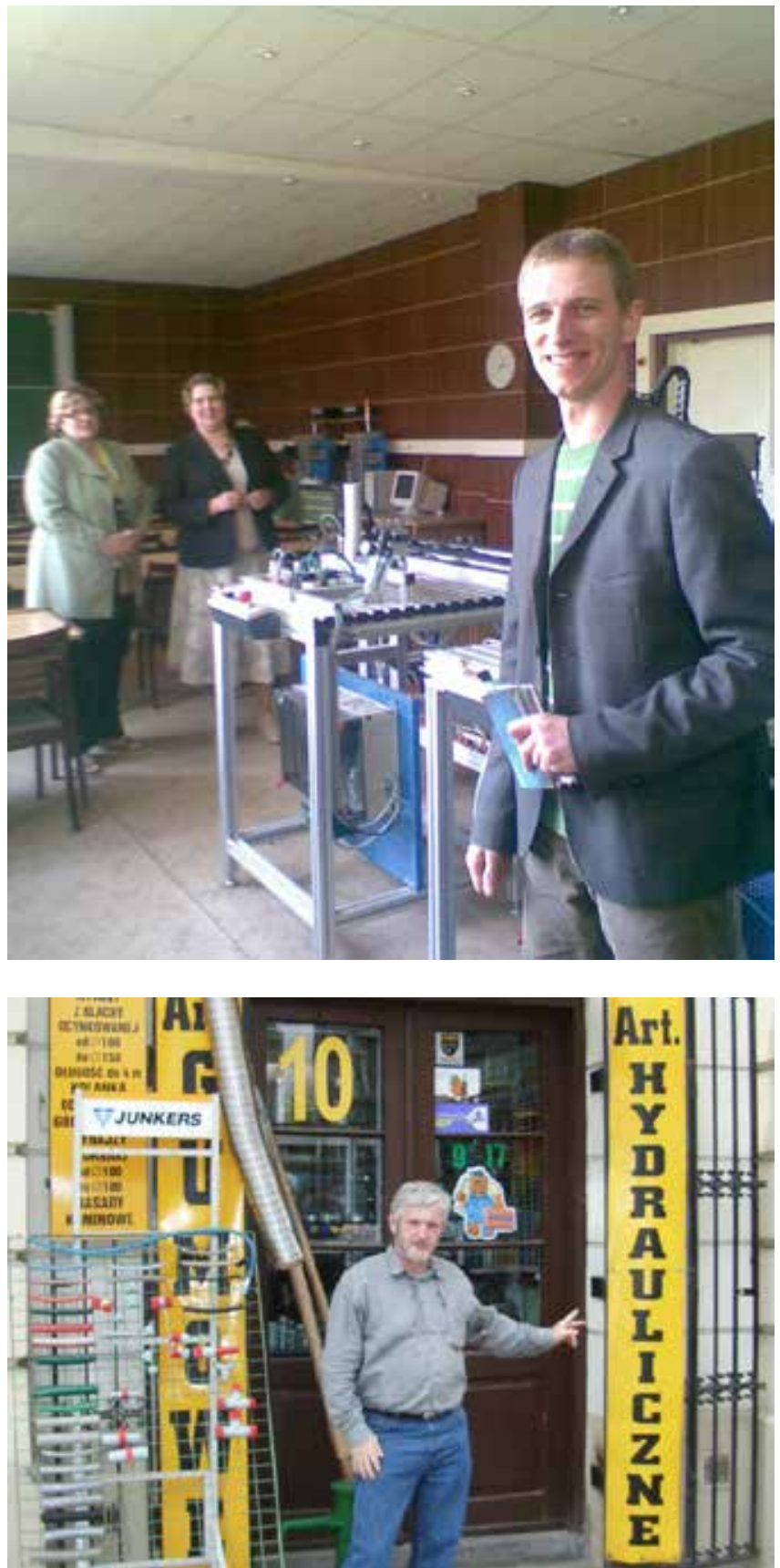
Inspiration fra australsk til dansk EUD

- Studierejse til Australien, oktober 2002

- Benny Wielandt, TEC Gladsaxe

- Rapport og artikler i DTL/LvA's fagblad

\section{Studierejse til Estland for at studere} den estiske EUD-reform

- Studierejse til Estland, juni 2004

- Benny Wielandt, TEC Gladsaxe

- Rapport: Estisk for begyndere

- Artikler i Vejlederen, Gymnasieskolen og Erhvervsskolelæreren

Kompetencebaseret EUD-undervisning i Irland. Fordele og ulemper ved det kompetencebaserede system

- Studierejse til Irland, februar 2006

- Benny Wielandt og Tonny Munnecke, TEC Gladsaxe

- Rapport: EIIL-støttet rejse til Irland

- Artikel i Erhvervsskolelæreren

Den polske blikkenslager. En undersøgelse af stærke/innovative sider i et østeuropæisk EUD-system

- Studierejse til Polen, april 2007

- Benny Wielandt, TEC Gladsaxe

- Rapport for EIIL-aktiviteten "Den polske blikkenslager"

- Workshop lærerefteruddannelse
På sporet af Jan Comenius: EUD i Tjekkiet og Slovakiet

- Studierejse til Tjekkiet og Slovakiet, april 2009

- Benny Wielandt, TEC Gladsaxe

- Rapport for EIIL-aktiviteten "Rejse til Comenius-land"

- Artikler i Vejlederen og TEC på tryk

\section{De baltiske tigres}

erhvervsuddannelser. At undersøge erhvervsuddannelser i Letland og Litauen med henblik på inspiration til dansk praksis

- Studierejse til Letland og Litauen, maj 2010

- Benny Wielandt, TEC Gladsaxe

- Rapport for EIIL-aktiviteten "De baltiske tigres erhvervsuddannelser"

- Artikel i Vejlederen

Gullasch, Dracula og EUD. Studierejse til Ungarn og Rumænien

- Studierejse til Ungarn og Rumænien, maj 2011

- Benny Wielandt, TEC Gladsaxe

- Rapport for EIIL-aktiviteten "Gullasch, Dracula og EUD”

- Artikel i Vejlederen 



\section{MEROPnL}

Nationalt Center for

Erhvervspædagogik

Tagensvej 18

2200 København N

www.phmetropol.dk

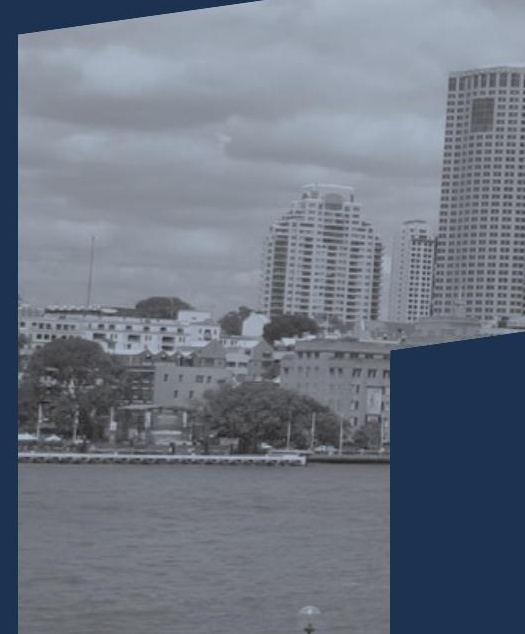

